\title{
The endemic and morphologically remarkable nautilid genus Deltocymatoceras Kummel, 1956 from the Late Cretaceous of Central Europe
}

\author{
JIŘí FRANK, MARKUS WILMSEN \& MARTIN KOŠŤÁK
}

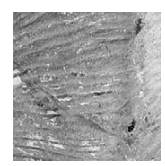

\begin{abstract}
The endemic Late Cretaceous nautilid genus Deltocymatoceras Kummel, 1956 is represented by Deltocymatoceras leiotropis (Schlüter, 1876) and D. rugatum (Fritsch \& Schlönbach, 1872). Characteristic for this genus is a bulbous involute shell with strong radial ribbing and a ventral keel, which appears in post-juvenile ontogenetic stages. The combination of these morphological features is unique among post-Palaeozoic nautiloids. Both species are restricted to the Late Turonian-Middle Coniacian of Central Europe and England. Until now, the type species D. leiotropis was known based only on the holotype specimen. This specimen is re-described with revised occurrence and for the first time photographically illustrated. The only preserved syntype from the type specimens of D. rugatum was re-discovered during this revision and more than thirty other specimens were studied. Representatives of Deltocymatoceras show clear morphological changes during their ontogeny and acquisition of maturity, most notably the appearance of a ventral keel in premature stages and its disappearance at maturity. The hypothesis of a close phylogenetic affinity of Deltocymatoceras to the genus Cymatoceras Hyatt, 1884 is based on similar morphological features such as the suture, ribbing, shell shape and early ontogenetic development. The ventral keel is quite an exceptional feature of morphology in post-Palaeozoic nautiloids. In particular the combination with an involute depressed shell is only shared with representatives of the genus Angulithes Montfort, 1808 (Cretaceous-Palaeogene) and Gryponautilus Mojsisovic, 1902 (Triassic). The combination with a compressed and evolute planispiral shell is more common in Palaeozoic and some post-Palaeozoic nautiloids. The ventral keel is discussed here in relation to its functional aspects (hydrodynamic stability) in combination with the strong radial ribbing (protection of the shell against mechanical damage). The appearance of the genus concurred with the late Turonian shallowing/cooling associated with the "Hyphantoceras Event" and the availability of an ecologic niche (i.e., absence of medium-sized, keeled ammonites at that time). Low abundance, an endemic occurrence, and the very short stratigraphic range of the genus ( $3.5 \mathrm{Ma})$ reflect the limited evolutionary success of the Deltocymatoceras lineage. - Key words: Nautilida, taxonomy, phylogeny, ontogeny, palaeogeography, functional morphology, biostratigraphy.
\end{abstract}

FrAnK, J., Wilmsen, M. \& KoŠŤÁK, M. 2013. The endemic and morphologically remarkable nautilid genus Deltocymatoceras Kummel, 1956 from the Late Cretaceous of Central Europe. Bulletin of Geosciences 88(4), 793-812 (8 figures, 1 table, 1 appendix). Czech Geological Survey, Prague. ISSN 1214-1119. Manuscript received December 3 , 2012; accepted in revised form May 17, 2013; published online September 12, 2013; issued October 31, 2013.

Jiři Frank, Institute of Geology and Palaeontology, Faculty of Science, Charles University, Albertov 6, 12843 Praha 2, and National Museum, Department of Palaeontology, Václavské náměstí 68, 11579 Praha 1, Czech Republic; jiri_frank@nm.cz・Markus Wilmsen, Senckenberg Naturhistorische Sammlungen Dresden, Museum für Mineralogie und Geologie, Sektion Paläozoologie, Königsbrücker Landstrasse 159, D-01109 Dresden, Germany; markus.wilmsen@senckenberg.de•Martin Košták, Institute of Geology and Palaeontology, Faculty of Science, Charles University, Albertov 6, 12843 Praha 2, Czech Republic; martin.kostak@natur.cuni.cz

Late Cretaceous nautilids are morphologically much less diverse and fairly long-ranging compared to contemporaneous ammonites. Thus they seem less attractive for systematic and stratigraphic studies. The genus Deltocymatoceras is an exception due to the conspicuous strong radial ribbing, the prominent ventral keel, short stratigraphic range and endemic occurrence. The ventral keel especially is a rare morphological feature within nautilids, particularly in combination with a depressed shell. There are only a few known genera with this combination of features such as Gryponautilus Mojsisovic, 1902 (Triassic) and Angulithes Montfort, 1808 (Cretaceous). In contrast, ribbing is a common feature especially within the Cretaceous nautilids of the genus Cymatoceras. In the same epoch as Deltocymatoceras, nautilids with prominent ventral keels such as $A n$ gulithes and with various types of radial ribbing such as Cymatoceras occurred. However, only Angulithes galea (Fritsch \& Schlönbach, 1872; see discussion in Frank 


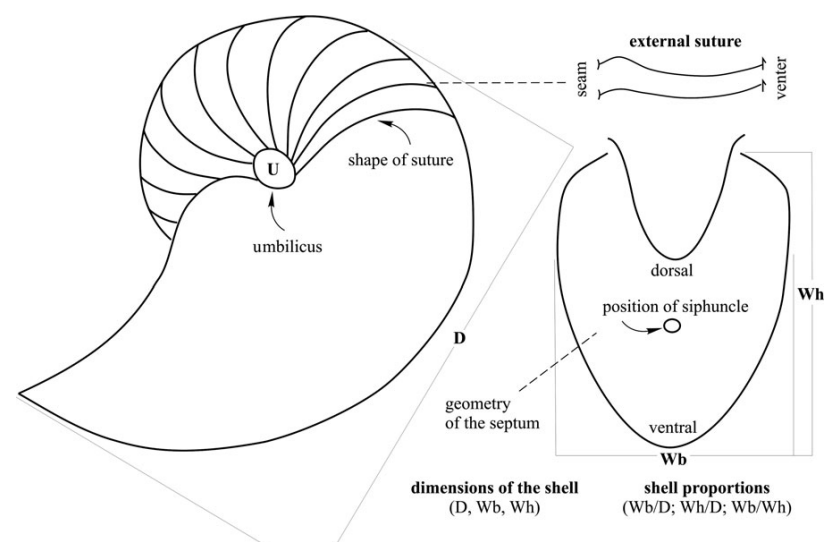

Figure 1. Morphological features in nautilid biometry and systematics (modified from Wilmsen \& Esser 2004, Frank 2010).

2010) displays this combination of characters on the last third of the living chamber of mature shells. Furthermore, the fold-like-ribs of $A$. galea occur when the keel is reduced and disappeared. In our opinion, these traits indicate a close phylogenetic relationship between Angulithes and Cymatoceras rather than shell convergence (polyphyly homoplasy). In this paper we discuss the phylogeny of the genus and its affinity to Cymatoceras [see Kummel 1956; probably C. radiatum (Sowerby, 1822)], and Angulithes [A. triangularis (Montfort, 1808); see Wilmsen 2000]. Despite the low diversity of Deltocymatoceras with only two species and its limited geographic distribution, it is retained as a separate genus based on its specific morphological characters. Ontogenetic trends during the acquisition of maturity are comparable to those documented in recent nautilids (Collins \& Ward 1987, Frank 2010). Nevertheless, mature shell modifications are more common and more strongly developed in several early Palaeozoic nautiloids (e.g. Teichert 1964, Stridsberg 1985, Manda 2008). Furthermore, we also discuss the functional morphology of Deltocymatoceras. Finally, we evaluate paleoecology and distribution pattern of the genus Deltocymatoceras.

\section{Material and methods}

This study has involved the majority of all known specimens of the genus housed in European institutional collections in Europe and new records from field sampling. Deltocymatoceras rugatum is currently represented by 22 specimens and Deltocymatoceras leiotropis by 10 specimens. Eight specimens are in open nomenclature (see appendix).

The studied material is reposited in the following institutions: Národní muzeum, Prague, the Czech Republic (NM); Chlupáčovo muzeum historie Země, Institute of
Geology and Palaeontology, Faculty of Science, Charles University, Prague, the Czech Republic (CHM UGP); Polabské muzeum, Nymburk, the Czech Republic (PMN); Muzeum Českého ráje, Turnov, the Czech Republic (MCR); Orlické muzeum, Choceň, the Czech Republic (OM); Úpohlavy quarry, the Czech Republic; Regionální muzeum v Teplicích, the Czech Republic (RMT); Muzeum Železnice, the Czech Republic (MZ); Senckenberg Naturhistorische Sammlungen Dresden, Museum für Mineralogie und Geologie, Germany (MMG); Goldfuss-Museum, Bonn, Germany (GMB). Ruhr-Museum Essen, Germany (RME); Museum für Naturkunde, Berlin, Germany (MfN); Naturhistorisches Museum Wien, Austria (NMW); Natural History Museum London, the United Kingdom (NHM); British Geological Survey, Keyworth, the United Kingdom (BGS). The material from Wittler et al. (1999) is not kept in a recognized institution but has been evaluated based on the illustrations provided in the aforementioned paper.

Standard measurements of all specimens were obtained using a sliding calliper (see Fig. 1). D = maximum diameter; $\mathrm{Wb}=$ maximum width of the whorl; $\mathrm{Wh}=$ maximum height of the whorl; ratios are $\mathrm{Wb} / \mathrm{D}, \mathrm{Wh} / \mathrm{D}$ and $\mathrm{Wb} / \mathrm{Wh}$ (shells with $\mathrm{Wb} / \mathrm{Wh}>1$ are depressed, those with $\mathrm{Wb} / \mathrm{Wh}<1$ are compressed). The most important features for taxonomic analyses are: the position of the siphuncle; the suture pattern; general form of the shell and the whorl cross-section; the character and width of the umbilicus, and the surface ornamentation of the shell; detailed morphological features and terms as in Teichert (1964). However, most of the specimens are deformed or only partly preserved, and thus biometric data are often incomplete.

\section{Systematic palaeontology}

Order Nautilida Agassiz, 1847

Family Nautilidae Blainville, 1825

\section{Genus Deltocymatoceras Kummel, 1956}

Type species. - Nautilus leiotropis Schlüter, 1876.

Emended diagnosis. - Nautiliconic, involute, depressed to slightly compressed shells with convex, broadly arched and convergent sides. Whorl cross-section with rounded to sharply angular venter, overlapping approximately one third of the preceding whorl. With prominent, slightly rounded ventral keel appearing in post-juvenile stage, smooth or moderately wrinkled by crossing radial ribs. Shell ornamented with strong radial ribs, bifurcating in approximately the middle of the flanks. Suture moderately sinuous with narrowly rounded saddle on the inner flanks, 
broad, more or less shallow lateral lobe on the outer flanks and narrowly rounded to pointed ventral saddle. Position of siphuncle central/ventro-central.

Discussion. - Kummel (1956, p. 439) considered Deltocymatoceras as being derived from Cymatoceras due to the corresponding radial ribbing and he combined both genera in the subfamily Cymatoceratinae Spath, 1927, later he included both genera in the family Cymatoceratidae Spath, 1927 (Kummel 1964, p. 454). Kummel (1956, p. 439) described Deltocymatoceras as homeomorphic with Angulithes with respect to the shape of the shell and suture line. Wiedmann (1960, pp. 149, 174) regarded Deltocymatoceras as a subgenus of Angulithes and D. leiotropis as well as D. rugatum as sculptured forms of the subgenus. Shimansky (1975) discarded the family Cymatoceratidae and grouped Deltocymatoceras and Cymatoceras together in the family Nautilidae and synonymized Angulithes with Deltoidonautilus, including the latter genus in the family Hercoglossidae Spath, 1927. Matsumoto \& Muramoto (1983, p. 89) proposed that Deltocymatoceras (of the family Cymatoceratidae) is convergent with Angulithes based on the specific suture line and shell shape. They compared the type species Deltocymatoceras leiotropis with that of Angulithes, A. triangularis. Dzik (1984, p. 180) also discussed the affinity of Deltocymatoceras and Angulithes, and noted the close relationship between the two type species. Based on the radial ribbing, Wilmsen (2000, pp. 37-38) supported separation of Deltocymatoceras and Angulithes, but he proposed keeping the two genera in one family, Nautilidae Blainville, 1825 . We agree with the interpretation that Deltocymatoceras is derived from Cymatoceras but we are also aware of inconsistencies in the systematics of the family Cymatoceratidae (Tintant 1989, Frank 2010). The relative importance of traits such as radial ribbing, the suture, the keel or the position of the siphuncle for systematic classification is still under debate.

Stratigraphic and geographic range. - Both species occurred in the early Late Turonian of the Czech Republic and Germany; D. rugatum also occurred in the early Late Turonian of Poland; D. leiotropis also occurred in the Late Turonian of England and Germany, in the Early Coniacian of the Czech Republic and in the Middle Coniacian of Germany and Poland.

\section{Deltocymatoceras leiotropis (Schlüter, 1876)}

Figures 3, 8J-K

1876 Nautilus leiotropis; Schlüter, p. 175, pl. 47, figs 1, 2.

1934 Nautilus leiotropis (Schlüter). - Andert, pp. 390-392, text-fig. 91.
1956 Deltocymatoceras leiotropis (Schlüter). - Kummel, pp. 438-439, pl. 22, figs 1, 2.

1960 A. (Angulithes) leiotropis (Schlüter). - Wiedmann, p. 193.

1964 Deltocymatoceras leiotropis (Schlüter). - Kummel, p. 454 , pl. 334 , fig. $5 \mathrm{a}$, b.

1975 Deltocymatoceras leiotropis (Schlüter). - Shimansky, pp. 122-123, tab. 31.

1983 Deltocymatoceras leiotropis (Schlüter). - Matsumoto \& Muramoto, p. 89.

1983 Deltocymatoceras leiotropis (Schlüter). - Kabamba, pp. 90-91.

1983 Deltocymatoceras n. sp.; Kabamba, pp. 91-93, pl. 7, fig. 5a, 5b.

1984 Deltocymatoceras leiotropis (Schlüter). - Dzik, p. 180.

1999 Deltocymatoceras leiotropis (Schlüter). - Wittler, Roth \& Legant, pp. 32-35, text-figs 45a, b, 46a, b.

non 2000 possible transitional form between Angulithes and Deltocymatoceras Kummel, 1956; Wilmsen, pp. 37-38 [A. triangularis].

2009 Deltocymatoceras leiotropis (Schlüter). - Frank, p. 13.

2010 Deltocymatoceras leiotropis (Schlüter). - Frank, p. 494 , fig. 5 e, f, g.

Holotype (by monotypy). - Specimen GM 96 figured by Schlüter (1876) on pl. 47 as fig. 3; Goldfuss-Museum, Bonn, Germany (Fig. 3).

Type locality. - Hercules mine near Essen, Germany.

Type horizon. - In the original description of Nautilus leiotropis, Schlüter (1976, p. 175) stated that the single specimen is from the Emscher-Mergel (Emscher Formation, Middle Coniacian-Santonian) of the coal mine Hercules shaft in the centre of Essen. However, the Emscher Formation does not reach that far south in the area of Essen (see Pieper 1990) and the approximately $30 \mathrm{~m}$ deep shaft went through Middle-Upper Turonian marly-glauconitic sediments (Salder and Oerlinghausen formations in proximal greensand facies), Lower Turonian marls (Büren Formation) and Cenomanian greensands (Essen Greensand Formation) before reaching the coal-bearing Carboniferous. Thus, the stratigraphic assignment by Schlüter (1976) is incorrect and the holotype is of Turonian, most likely Late Turonian age.

Description. - The shell is nautiliconic, involute and oval with an almost closed umbilicus. The whorl-section is slightly depressed $(\mathrm{Wb} \approx 170 \mathrm{~mm}, \mathrm{Wh} \approx 130 \mathrm{~mm}$; $\mathrm{Wb} / \mathrm{Wh} \approx 1.3$ ) in late ontogeny and adulthood (maturity). The flanks are convex and the maximum width of the whorl cross-section is on their inner part. The whorl crosssection is more or less triangular in late ontogeny due to the ventral keel. The ventral keel is very prominent, narrowly 


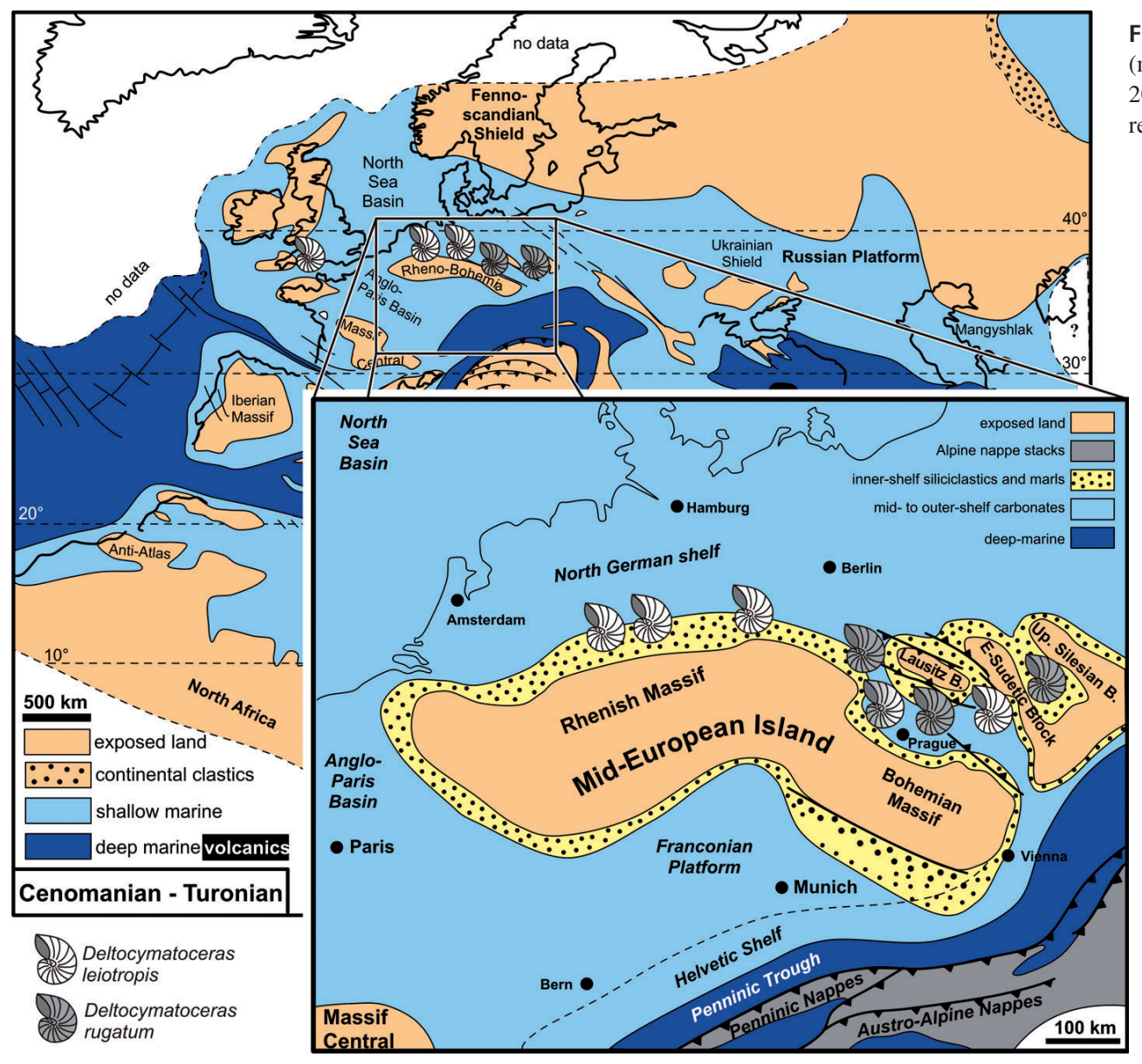

Figure 2. Palaeogeographic maps (modified from Philip \& Floquet 2000 and Ziegler 1990) with occurrences of Deltocymatoceras.

rounded, smooth or weakly wrinkled by crossing radial ribs. The keel appears on the last and probably also on the penultimate whorl. The keel on the fully-grown shell (D $\geq 290 \mathrm{~mm}$ ) gradually decreases in the apertural area. The maximum size (D) of the shell is estimated to exceed $300 \mathrm{~mm}$. The whole shell is covered by strong radial ribs, which originate at the umbilicus. They are initially thin and widen on the flanks with a broad, shallow, convex sinus, irregularly bifurcating predominantly on the inner and mid-flank. Ventro-laterally and ventrally, the ribs reach their maximum width $(\sim 6 \mathrm{~mm})$. They cross this area with a broad shallow sinus. In the middle of the venter, the ribs are crossed by the keel or they weakly traverse it. The ribs become broader on the body chamber in late ontogeny. The suture (Fig. 4A) is sinuous with a small shallow umbilical lobe, a narrow and regularly rounded saddle on the umbilical margin and on the inner flank, and with a broad shallow ventro-lateral lobe, and a prominent ventral saddle, which is accentuated by the ventral keel. The septa are relatively distant from each other, approximately 16-18 per whorl in the type specimen, creating large phragmocone chambers. The position of the siphuncle is unknown.

The holotype GM-42 (96) (Fig. 3) is deformed and slightly askew. The ventral keel is very prominent. The sur- face of the keel is smooth and no ribbing is preserved on it. The ribs cover the rest of the shell and are remarkably large on the body chamber $(\approx 6 \mathrm{~mm})$ in contrast to the width of the ribs on the previous phragmocone chambers $(\approx 3 \mathrm{~mm})$ on the ventral side. The last relatively large septa are not approximated, which could indicate that this specimen $(\mathrm{D} \approx 250 \mathrm{~mm}$ ) had not attained maturity when it died. This is corroborated by the ventral keel, which is still prominent on the whole body chamber (but has faded away in adult specimens). The aperture is not preserved. Accordingly, $250 \mathrm{~mm}$ is not the maximum shell diameter of this species.

Specimen MB.C.15024 (Fig. 8J, K) is described based on an excellent quality plaster cast of the specimen from the Halberstadt Formation (Middle Coniacian) at the Lehofsberg near Quedlinburg (Saxony-Anhalt, Germany). This specimen has prominent ribs and the ventral keel preserved, and it probably represents a full body chamber with the last 2-3 phragmocone chambers being present. The ventral keel is somewhat less prominent compared to the holotype and the ribs are only weakly visible on the keel. This specimen is probably mature or almost mature due to the reduced ventral keel in the apertural area, the shape of the body chamber and the diameter of the shell $(\mathrm{D} \approx 290 \mathrm{~mm})$. 

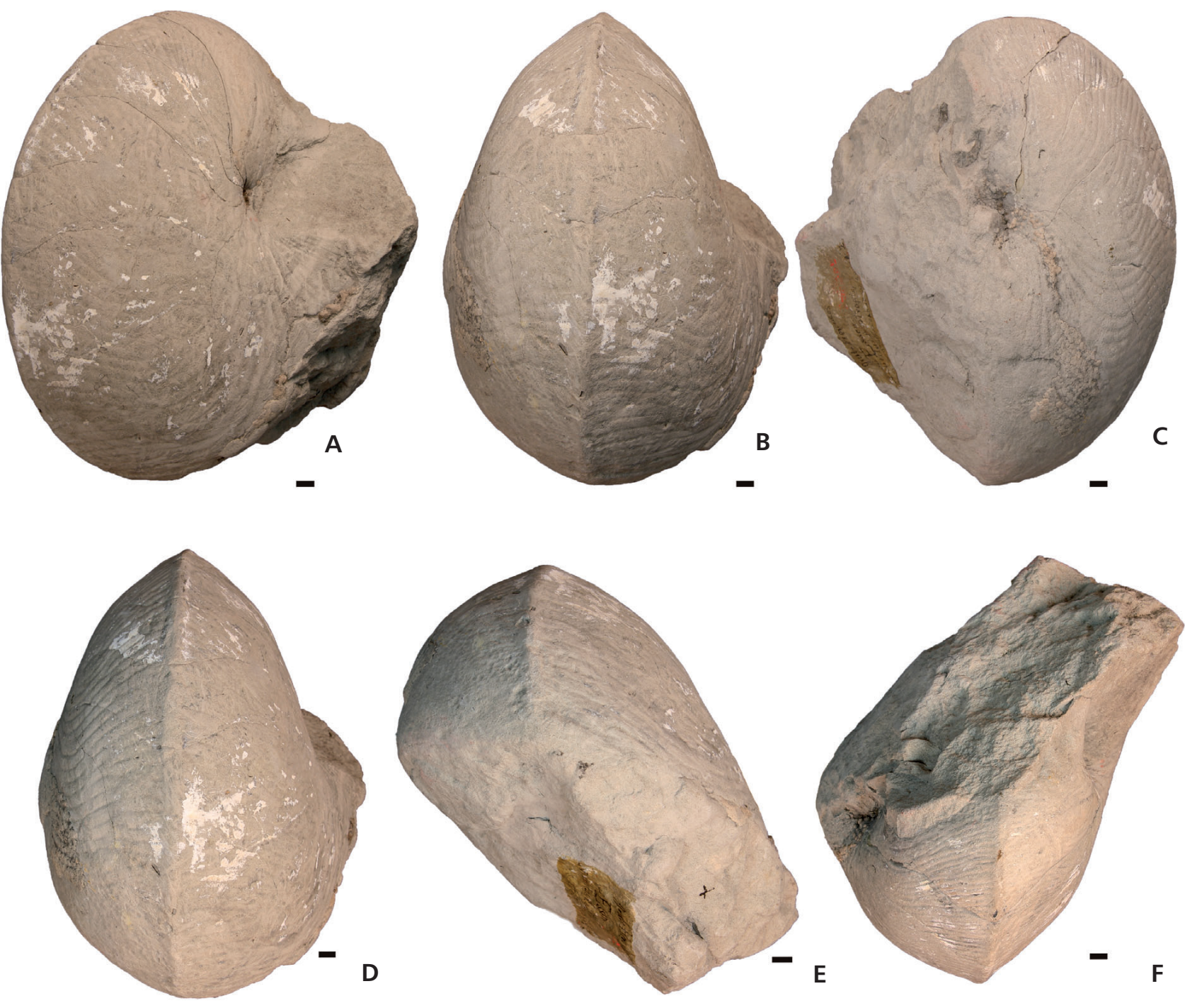

Figure 3. Deltocymatoceras leiotropis (Schlüter, 1876), holotype GM 96 (the scale bar is $10 \mathrm{~mm}$ ). • A - right lateral side; B - ventral side; C - left lateral side; D - ventral side partly posterior view with septa; $\mathrm{E}$ - ventral side anterior view; $\mathrm{F}$ - ventral side posterior view.

Discussion. - D. leiotropis differs (Table 1) from D. rugatum, in having a one third larger maximum shell size, relatively less wide/thick (strength) ribs, a more prominent ventral keel and different shape of the suture line. The ribs of D. rugatum are more robust (thicker and taller) and cross the less prominent ventral keel.

The early Campanian Angulithes westphalicus (Schlüter, 1872) is similar to D. leiotropis in shell diameter size in the fully grown shell $(\mathrm{D} \approx 250 \mathrm{~mm}$ ) and shape of the slightly depressed whorl cross section. The appearance of the ventral keel is also similar. A. westphalicus differs in the shape of its suture line which is more sinuous. The most noticeable difference is the lack of radial ribbing in A. westphalicus which has a smooth surface covered only by growth lines. An exception is the early Late Turonian Angulithes galea (Fritsch \& Schlönbach, 1872), in which strong radial rib-like-folds appear in the adapertural area in the late premature stage, followed by a reduction of the keel (Frank 2010). This keel reduction is similar in D. leiotropis and D. rugatum. Furthermore, the Late Cenomanian A. vascogothicus (Wiedmann, 1960) develops ventral folds on the last whorl (Wilmsen 2000), but these undulations have a different shape and morphology compared to the ribs in Deltocymatoceras. A. galea differs from D. leiotropis in having a shallower lateral lobe and a very shallow ventral saddle on the suture line. Matsumoto \& Muramoto (1983, p. 89) and also Dzik (1984, p. 180) compared D. leiotropis to A. triangularis. These species are similar in their sinuous sutures, which have a relatively deep lateral lobe and narrow ventral saddle. Nevertheless, the suture line of A. triangularis is slightly more sinuous, the whorl cross section is more triangular and less depressed than in D. leiotropis. Furthermore, A. triangularis has a somewhat smaller maximum shell size and the shell is smooth. 
Table 1. Comparison of different features in Deltocymatoceras leiotropis and D. rugatum.

\begin{tabular}{ll}
\hline Deltocymatoceras leiotropis & Deltocymatoceras rugatum \\
\hline Maximum size of the shell (D) $\sim 290 \mathrm{~mm}$ & Maximum size of the shell (D) 200 mm \\
\hline $\begin{array}{l}\text { Size and form of ribs on the ventral side: } \\
\text { flattened; }\end{array}$ & $\begin{array}{l}\text { Size and form of ribs on the ventral side: } \\
\text { rounded; } \\
\sim 3 \mathrm{~mm} \text { on the phragmocone in late ontogenetic stage; }\end{array}$ \\
$\sim 6 \mathrm{~mm}$ on the living chamber of same stage; space between ribs $\sim 1 \mathrm{~mm}$. & $\sim 8-9 \mathrm{~mm}$ on the living chamber of same stage; \\
& space between ribs $\sim 2-3 \mathrm{~mm}$. \\
\hline $\begin{array}{l}\text { Ventral keel: very prominent, narrow, smooth or slightly wrinkled by crossing ribs. } \\
\text { Suture line: }\end{array}$ & Ventral keel: less prominent, broader, crossed by strong ribs. \\
$\begin{array}{l}\text { narrow saddle on the venter; } \\
\text { shallow lobe on the outer part of lateral side; }\end{array}$ & $\begin{array}{l}\text { Suture line: } \\
\text { broad shallow saddle on the venter; } \\
\text { narrow prominent saddle on umbilical wall. }\end{array}$ \\
\hline
\end{tabular}

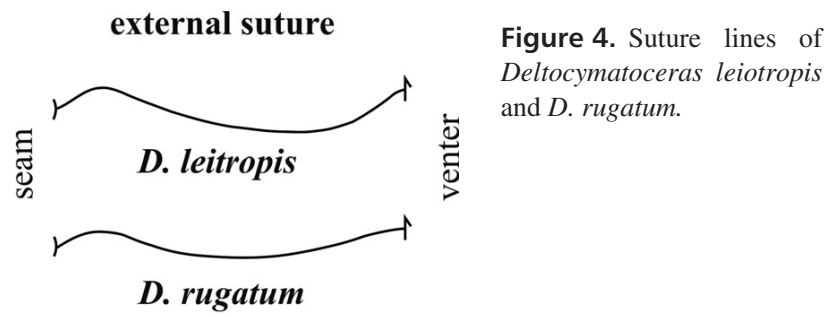

Cymatoceras patens (Kner, 1848) has a compressed whorl cross section in combination with moderately strong ribbing, but the ribs are not as robust as those in Deltocymatoceras. Cymatoceras loricatum (Schlüter, 1876) is likewise very involute with an almost closed umbilicus. Its whorl cross section is only weakly compressed $(\mathrm{Wb} / \mathrm{Wh} \approx 0.9)$ and it is characterized by prominent cymatoceratid ribbing (see Wilmsen \& Esser 2004 for details). As in C. patens, there is no keel during any growth stage.

Large specimens of D. leiotropis and D. rugatum are easy to identify, but juvenile specimens can easily be misinterpreted as representatives of Cymatoceras because of the radial ribbing and depressed whorl cross section. If the ribbing is not preserved, juveniles could even be misinterpreted as specimens of Eutrephoceras or Angulithes (Frank 2010).

Occurrence. - Late Turonian to Middle Coniacian of Germany, England, Poland and the Czech Republic (Fig. 2).

\section{Deltocymatoceras rugatum}

(Fritsch \& Schlönbach, 1872)

Figures 6, 8A-I

?1845-1846 Nautilus elegans Sow. - Reuss, p. 21.

1872 Nautilus rugatus; Fritsch \& Schlönbach, p. 23, pl. 12, fig. 2, pl. 15, fig. 2 .

non 1872-1875 Nautilus rugatus (Fritsch \& Schlönbach). - Geinitz, pp. 181-182, pl. 31, fig. 16 [= Angulithes galea].

?1876 Nautilus cf. rugatus (Fritsch \& Schlönbach). Schlüter, pp. 173-174.
1883 Nautilus rugatus (Fritsch \& Schlönbach). Frič, p. 90, text-fig. 50.

1885 Nautilus rugatus (Fritsch \& Schlönbach). Frič, p. 85, fig. 50.

non 1889 Nautilus rugatus (Fritsch \& Schlönbach). Frič, p. 70 [= Angulithes galea].

non 1893 Nautilus rugatus (Fritsch \& Schlönbach). Frič, p. 73 [= Deltocymatoceras leiotropis].

non 1897 Nautilus rugatus (Fritsch \& Schlönbach). Frič, p. 36 [= Angulithes galea $]$.

1910 Nautilus rugatus (Fritsch \& Schlönbach). Spengler, pp. 130-131.

1934 Nautilus rugatus (Fritsch \& Schlönbach). - Andert, pp. 390-392.

1960 A. (Angulithes) rugatus (Fritsch \& Schlönbach). - Wiedmann, p. 193.

?1999 ?Cymatoceras sharpei (Schlüter). - Wittler, Roth \& Legant, p. 22, text-fig. 26a, b.

?2002 Deltocymatoceras sp. - Kennedy, p. 230, pl. 42, figs 4-6, text-fig. 10-1e.

2007a Deltocymatoceras rugatus (Fritsch \& Schlönbach). - Frank, pp. 112-113, text-fig. 1(3).

2007b Deltocymatoceras rugatus (Fritsch \& Schlönbach). - Frank, pp. 35-36, text-fig. 1(3).

2009 Deltocymatoceras rugatus (Fritsch \& Schlönbach). - Frank, p. 13.

2010 Deltocymatoceras rugatus (Fritsch \& Schlönbach). - Frank, p. 494, pl. 5, figs a-d.

Type. - Fritsch \& Schlönbach (1872) mentioned several specimens in the original description of D. rugatum. According to a previous revision (Frank 2010), several of these specimens belong to Angulithes galea. Unfortunately, all the specimens assigned to D. rugatum by Fritsch \& Schlönbach (1872) are missing, except for specimen O 3164 (Fig. 6G-I) from Choroušky, which was originally illustrated and is located in the collections of the National Museum in Prague (note that the figure in Fritsch \& Schlönbach 1872 is horizontally orientated). The surface morphology of this specimen is only partly preserved. Furthermore, the ventral side is in some parts fixed by plaster 
and the ribs in this area are partly sculptured. The ventral keel is also poorly preserved. Even after a number of years, we were not successful in re-locating the other syntypes from the Frič collection, but we found additional specimens in the collection of the National Museum, which correspond well with the original description of Nautilus rugatus. From these specimens we selected a neotype candidate (O 6039, Fig. 6A-F). We recommend requesting the international commission on zoological nomenclature under its plenary power to set aside the existing namebearing type (syntypes O 3164) and to designate a neotype (O 6093) in terms of retaining stability and universality of this taxon. This specimen is the best candidate as it exhibits all the taxonomic features described in Fritsch \& Schlönbach (1872). Furthermore, it is from the same locality and horizon as specimen O 3164. This specimen was, with high probability, studied by Frič himself and could be considered as a part of his collection. The specimen is deposited in the National Museum, Prague, the Czech Republic.

Type locality. - Choroušky near Mělník, Central Bohemia, the Czech Republic.

Type horizon. - Trigonia/Choroušky Beds (sensu Frič 1885), Jizera Formation, lower Upper Turonian, probably Subprionocyclus neptuni and Inoceramus perplexus zones.

Description. - Nautiliconic, involute and oval shell, with closed umbilicus. Depressed whorl cross-section $(\mathrm{Wd} \approx 110 \mathrm{~mm} ; \mathrm{Wh} \approx 95 \mathrm{~mm} ; \mathrm{Wd} / \mathrm{Wh}=1.2)$ with convex lateral sides, broadly rounded venter and slightly trigonal shape in late ontogeny due to the ventral keel. Maximum width is on the inner flank. The ventral keel appears on the last and penultimate whorl. The keel is blunt, narrowly rounded and weakly to moderately wrinkled by crossing radial ribs. The height of the keel gradually decreases in the apertural area on the fully-grown shell $(\mathrm{D} \approx 190 \mathrm{~mm})$. In this area, the whorl cross-section is depressed with a broadly rounded venter. The maximum size (D) of the shell is $\approx 210 \mathrm{~mm}$. The ventral keel did not develop during early growth stages, but the whole shell was crossed by robust radial ribs throughout ontogeny. Ribs originate at the umbilicus, where they are thin, and broaden across the flanks with a broad shallow convex curve, irregularly bifurcating, predominantly on the inner and mid-flank. Close to and on the venter, the ribs reach their maximum width $(\approx 8-9 \mathrm{~mm}$ during the stage of late ontogeny) and cross this area with a broad shallow sinus. The ribs weakly traverse the ventral keel. The suture (Fig. 4B) is moderately sinuous with a small shallow umbilical lobe, a shallow umbilical saddle on the inner flank, followed by a very shallow lateral lobe, and a saddle on the venter. The position of the siphuncle is central to ventro-central.
The syntype O 3164 (Fig. 6G-I) (D = $120 \mathrm{~mm}$ ) has strong radial ribs on part of the left lateral side and on part of the frontal venter. The ribbing or other ornamentation is not preserved on the rest of the shell. The ventral side has in some parts been repaired by plaster and the ribs in this area are partly reconstructed. The whorl cross-section is depressed. The ventral keel is hardly recognisable due to poor preservation. The candidate neotype specimen O 6093 (Fig. 6A-E) is from the same locality and horizon as the syntype. Very strong radial ribbing is preserved on the shell and is more concentrated in the apertural area. This concentration is accompanied by a reduction of the ventral keel, interpreted as a character associated with the attaining of maturity. Its adult aperture is preserved with a noticeable constriction. Accordingly, this specimen shows more or less maximum shell size $(D \approx 200 \mathrm{~mm})$. A similar smaller specimen O 6417 (Fig. 8A-C) from the same collection and locality, displays the absence of a ventral keel on the younger whorl and its appearance during ontogeny. Specimens MMG SaK 8469 (Fig. 8D, E) and MMG SaK 8471 (Fig. 8F, G) are of a smaller size $(\mathrm{D} \approx 70-80 \mathrm{~mm}$ ) and represent early ontogenetic stages of $D$. rugatum with very strong ribbing. Unfortunately, both specimens are deformed, although the dorso-ventral deformation indicates the absence of a keel.

Discussion. - Several specimens of Angulithes galea were interpreted as $D$. rugatum due to the strong radial rib-like folds in the apertural area in late ontogeny $(D \approx 290 \mathrm{~mm}$; Frank 2010). This ribbing is interpreted by Frank (2010) as a mature character. A. galea differs from D. rugatum in the maximum diameter of the shell $(\mathrm{D} \approx 290 \mathrm{~mm}$ versus $\mathrm{D} \approx 190 \mathrm{~mm}$ ) and by a smooth shell surface covered by growth lines. Both species have a conspicuous ventral keel. Angulithes vascogothicus is medium-sized (D = 130-150 mm) and only weakly compressed, characterized by an ovoid to triangular whorl cross-section with maximum breadth on the inner flank. A. vascogothicus has coarse fold-like undulations on the outer flanks of the last whorl (Wilmsen 2000). However, these undulations are not real ribs but folds restricted to a specific part of the shell; furthermore, they are much broader than in D. rugatum. The suture is more sinuous than in D. rugatum. The ribbing is robust even on juveniles of D. rugatum and is a feature, which differs from that in juveniles of Cymatoceras. Exceptions are juveniles of $C$. radiatum (Sowerby, 1822), C. huxleyanum (Blanford, 1861), C. columbinum (Fritsch \& Schlönbach, 1872) and C. deslonghampsianum (d'Orbigny, 1840). The latter species has characteristic strong ribs crossed by linear lines creating a reticular structure throughout ontogeny. However, these fine structures are not always preserved. Nevertheless, C. delongchampsianum differs from $D$. rugatum by a significantly sharp umbilical wall. Very strong radial ribs and a depressed shell 
are typical for Cymatoceras pseudoelegans (d'Orbigny, 1840) from the Early Cretaceous, but the ribbing of $D$. rugatum in late ontogeny is much stronger, also when compared to other representatives of Cymatoceras from the Late Cretaceous. C. columbinum has strong, but less robust ribs than $D$. rugatum. The suture line is similar with a slightly more prominent umbilical saddle and a shallower lateral lobe. The distance between septa (length of phragmocone chambers) is greater than in D. rugatum at the same ontogenetic stage. $C$. radiatum has very robust ribbing even in juveniles, which is comparable to $D$. rugatum. It has a depressed, rounded to slightly trapezoidal whorl crosssection and a centro-dorsal siphuncle. $C$. radiatum has no keel, but it is a suitable candidate as an ancestor of $D$. rugatum.

Occurrence. - Early Late Turonian of the Czech Republic, Germany and Poland.

\section{Phylogeny of Deltocymatoceras}

Deltocymatoceras may have evolved either from Cymatoceras (i.e., C. radiatum) or from Angulithes (A. triangularis). We support the former interpretation that it evolved from Cymatoceras as suggested by Kummel (1956, homeomorphism with Angulithes) and we agree partly with Dzik (1984, derivation from Cymatoceras). However, Angulithes and its possible phylogenetic affinity to Cymatoceras or $\mathrm{Ci}$ momia Conrad, 1866 need to be revised in the future.

Coarsely ribbed "cymatoceratid" nautilids are known from the Late Jurassic and range throughout the Cretaceous into the Palaeogene with a possible ancestry from Cenoceras Hyatt, 1883 (e.g., Kummel 1964, Dzik 1984). Angulithes appeared in the Albian and flourished throughout the Late Cretaceous and Palaeogene with a possible derivation from Cimomia or Hercoglossa Conrad, 1866 (Kummel 1956, p. 453). According to Wilmsen (2000, pp. 37-38, fig. 5), Deltocymatoceras is derived from Angulithes based on a potential transitional form between both genera. However, a re-evaluation of the questionable specimen showed that it represents more likely a fully grown specimen of $A$. triangularis with a strongly inflated shell. Regarding the presence of the prominent ribs that characterize and are considered as a primary character of Deltocymatoceras, it thus appears more likely that the genus was derived from Cymatoceras radiatum.

The genus Cymatoceras represents a rather diverse group containing approximately 64 species (Kummel 1956). It has been considered recently as polyphyletic (Matsumoto \& Muramoto 1983, Wilmsen 2000, Wilmsen \& Yazykova 2003, Cichowolski 2003). The main common character of Cymatoceras are the radial ribs, but the species differ in shell shape, suture lines and position of siphuncle.
However, if one compares early ontogenetic stages (up to 3-4 whorls) of the type species of the genus, C. pseudoelegans, or of $C$. radiatum with juveniles of $D$. rugatum, it is difficult to distinguish between them according to their shell shape, ornamentation and suture lines. C. pseudoelegans and especially $C$. radiatum have very strong ribs and depressed whorl cross-sections, very similar to D. rugatum, and a ventral keel is not present in early ontogenetic stages of both genera. The keel appears only in Deltocymatoceras during post-juvenile ontogeny. It was acquired later in phylogeny and is a secondary character, which is combined with the inherited strong radial ribs.

The limited evolutionary success of the genus Deltocymatoceras is reflected in its low diversity, endemic distribution and narrow stratigraphic range (Late Turonian-Middle Coniacian = approximately 3 million years according to the Geological Timescale 2012, Ogg \& Hinnov 2012). We speculate that the evolutionary experiment to combine an inflated, strongly ribbed shell with a prominent keel represented an evolutionary "blind alley".

\section{Functional morphology and ontogeny}

The combination of a prominent keel and strong ribbing in Deltocymatoceras is unique in post-Palaeozoic nautilids (Angulithes galea has these features but separately during ontogeny with folds-like-ribs). Thus, any interpretation of the functional morphology is difficult. With the exception of Deltocymatoceras and Angulithes, a keel in combination with a depressed shell appeared only in mature shells of Gryponautilus galeatus (Mojsisovics, 1873) from the late Triassic. Functional interpretations of a keel were usually related to hydrodynamics (Chamberlain \& Westermann 1976, Frank 2010), although such hypotheses are difficult to test. Such a keel might hypothetically have provided greater hydrodynamic stability for the shell and thus saved energy during inactivity (Westermann 1996, Frank 2010), and the keel ornamentation may have increased streamlining (Spath 1919). Keels are, however, usually developed in smooth, mainly compressed nautiloids (except for Deltocymatoceras), which are typical for pelagic, low-energy environments (Tintant \& Kabamba 1985, Wilmsen 2000). The ventral keel has variable shapes (usually flattened) and dimensions. Usually, the whole ventral side has an angular shape, narrowly rounded as for example in Heminautilus Spath, 1927 from the Cretaceous, or in Phacoceras Hyatt, 1884 from the Carboniferous and Permian. The angular shape of the narrowly rounded venters already appeared in nautiloids from the Early Ordovician (evolute shells of $\mathrm{Pi}$ lotoceras Cullison, 1944). Oxygonioceras oxynotum (Barrande, 1865) and $O$. discoideum (Barrande, 1866) from the late Silurian (see Manda \& Frýda 2010) also developed a prominent ventral keel on the depressed, evolute and 


\begin{tabular}{|c|c|c|c|c|c|c|c|c|}
\hline 泀 & 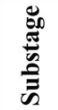 & $\begin{array}{c}\text { Amonite } \\
\text { zonation } \\
\text { (BCB) }\end{array}$ & $\begin{array}{l}\text { Inoceramid } \\
\text { zonation } \\
\text { (BCB) }\end{array}$ & $\begin{array}{c}\text { Saxo-Bohemian } \\
\text { Cretaceous } \\
\text { Basin }\end{array}$ & $\begin{array}{l}\text { Opole and Inner } \\
\text { Sudetic Cre- } \\
\text { taceous basins }\end{array}$ & $\begin{array}{c}\text { Subhercynian } \\
\text { Cretaceous } \\
\text { Basin }\end{array}$ & $\begin{array}{l}\text { Münsterland } \\
\text { Cretaceous } \\
\text { Basin }\end{array}$ & $\begin{array}{c}\text { NW Anglo- } \\
\text { Paris } \\
\text { Basin }\end{array}$ \\
\hline
\end{tabular}

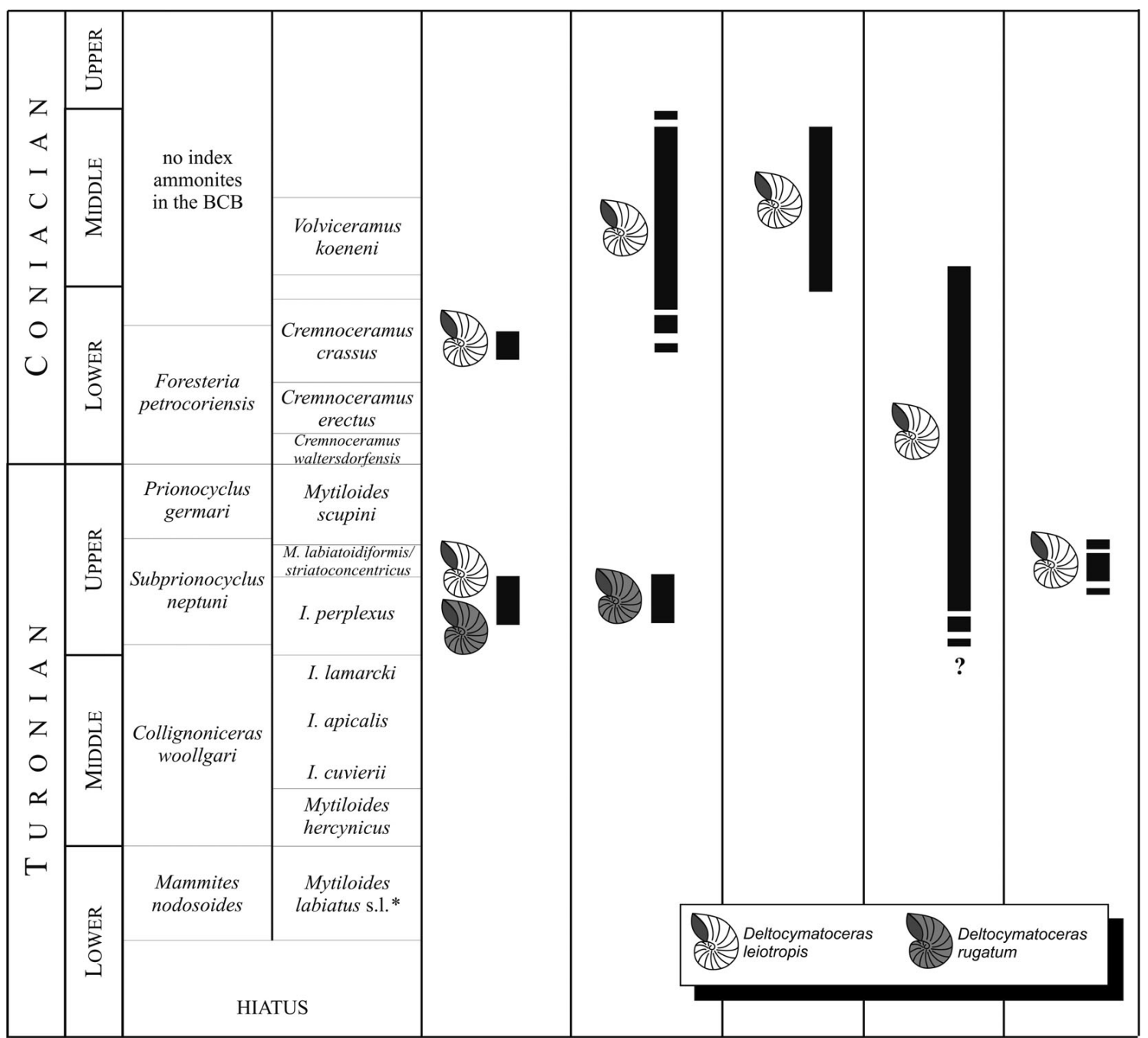

Figure 5. Stratigraphic distribution of Deltocymatoceras within European basins. Ammonite and inoceramid zonation after Košták et al. (2004). The dashed lines indicate the approximate extension of the occurrence.

slightly trochospiral shell. Keeled venters are also commonly found in ammonoids, for example in representatives of the order Prolecanitida. Barskov et al. (2008, p. 1228) mentioned that streamlined (compressed) shell shape together with a keel indicates good manoeuvrability in various shelf environments. The keel in several cephalopod groups thus played a different role, but the basic function seems to be stability control. Ribbing and tuberculation, however, result in decreased swimming abilities (Tsujita \& Westermann 1998).

In some Late Cretaceous ammonites - predominantly in placenticeratids with oxyconic shells (and many others), the elevated keel and the ornamentation (in some species i.e. nodes) are developed only in immature specimens (compare the analogy with Deltocymatoceras). The function of ribbing is still controversially discussed (e.g. Spath 1919, Westermann 1971, Chamberlain \& Westermann 1976, Tintant \& Kamamba 1985, Wilmsen \& Yazykova 2003, Chirat \& Bucher 2006). Certainly, it affects the hydrodynamic properties of any shell, but this effect will be less important for forms, which were poor swimmers (Chamberlain \& Westermann 1976), especially nautilids with depressed shells (Chamberlain 1976). When ribbing evolved in depressed forms such as in Deltocymatoceras, its function is thus probably not functionally related to hydrodynamics, especially when the ornamentation is more robust and prominent throughout ontogeny (Chamberlain \& Westermann 1976). Hypothetically, this kind of ribbing 
was a defensive trait (strengthening of the shell), either protecting the shell against mechanical damage in shallow turbulent water (Tintant et al. 1982, Tintant \& Kamamba 1985, Frank 2010, Wilmsen \& Mosavinia 2011) or against predators (e.g. Ward 1981, Signor \& Brett 1984, Wilmsen \& Yazykova 2003). Both interpretations could apply because Deltocymatoceras occurred in shallow environments and predation pressure by durophagous vertebrates increased throughout the Cretaceous (Vermeij 1977, Ward 1981, Gregory 2001). Highly elaborated sculptures occur in Devonian rutoceratoid nautilids and reflect an adaptation to life in high-energy environments (Manda \& Turek 2009a, 2011) rather than an anti-predatory feature (Signor \& Brett 1984). However, it is very difficult to test these hypotheses in Deltocymatoceras, partially because of the limited number of available specimens and their poor preservation.

The change in morphology of the Deltocymatoceras shell during ontogeny consists of the development and reduction of the ventral keel. The keel appears in an advanced ontogenetic stage as shown by specimen O 6417 (Fig. 8A-C). The keel persists into the late ontogenetic stage and its loss is interpreted as a consequence of the rounded broadening of the body chamber and subsequent weak apertural contraction. This stage is also followed by approximation of the last phragmocone chambers, but septal crowding usually occurs shortly before attaining maturity (Collins \& Ward 1987). These features are thus expressions of the approach of maturity, shared with some features of recent nautilids (Collins \& Ward 1987), and also comparable to the ventral keel of Angulithes (Frank 2010).

\section{Stratigraphic distribution}

The stratigraphic range of the genus Deltocymatoceras is very narrow. The first record is from the latest Middle?-early Late Turonian of Germany and the Czech Republic and the lineage ranges into the Mid-Coniacian. According to Ogg \& Hinnov (2012), this interval lasted about 3.5 million years. Compared to other long-ranging nautilid genera and even species [e.g., Angulithes fleuriausianus (d'Orbigny, 1840): Cenomanian-Coniacian, 15 million years] this is a very short period of time. This short stratigraphic range of the genus corresponds well with its endemic distribution (Fig. 2).

D. rugatum, after its systematic and taxonomic revision excluding related taxa, exhibits an even more limited stratigraphic distribution, i.e. it is confined to a narrow horizon in the early Late Turonian. A potential latest Middle Turonian occurrence is reported from East Bohemia (in the vicinity of Choceň).

The majority of records are from the lower part of the Teplice Formation in NW Bohemia and from the upper- most parts of the Jizera Formation (so called "Trigonia/Choroušky" beds by Frič 1885) in Central and East Bohemia. In the Teplice Formation, the stratigraphic range of D. rugatum corresponds to the "Hyphantoceras event" (Wiese et al. 2004) in the middle part of the Subprionocyclus neptuni Zone and the uppermost part of the Inoceramus perplexus Zone (Fig. 5). The stratigraphic data are supported by the ammonite fauna including Hyphantoceras reussianum (d'Orbigny), Subprionocyclus cf. branneri, Allocrioceras sp., and others (see Wiese et al. 2004), associated with the belemnite Praeactinocamax bohemicus (Stolley) (Košták et al. 2004, Košták \& Wiese 2011). New records from Úpohlavy (the Czech Republic) constrain the stratigraphic range and the FAD of D. rugatum. The earliest records from the section are reported herein from the base of the Teplice Formation ("Lower Coprolite Bed" sensu Wiese et al. 2004 - i.e. lithounit Xa sensu Zahálka (1900a, b). The highest abundance is recorded from the so-called Hudcov Limestone (Hundorfer Kalkstein sensu Frič 1889) or Zahálka's lithounit $\mathrm{Xb}_{\alpha}$. They are reported from former quarries at Čížkovice and Hudcov, and recently, these records have been confirmed from the Úpohlavy working quarry. All these records are from the $S$. neptuni Zone (middle part) and Inoceramus inequalis /I. lamarcki stuemckei / I. cuvieri /I. perplexus Zone (upper to uppermost part) sensu Wiese et al. (2004).

The second population of $D$. rugatum comes from Central and NE Bohemia, from the Jizera Formation. Records from the vicinities of Turnov and Jičín as well as from the Choroušky area are also of Late Turonian age ("Trigonia/Choroušky Beds" sensu Frič 1885). In particular the horizons bearing D. rugatum from the Jičín area (Železnice, Rovensko pod Troskami, etc.) are correlatable to $\mathrm{Xb}_{\alpha}$ in NW Bohemia. The accompanying ammonite assemblage of Lewesiceras mantelli (Wright \& Wright), L. peramplum (Mantell), Scaphites geinitzi (d'Orbigny), Allocrioceras strangulatum (Wright) and Baculites sp. (unpub. data, MK) corresponds to the typical so called "reussianum fauna" known from hemipelagic sediments of NW Bohemia (i.e. Úpohlavy, Čížkovice). Other records of D. rugatum from the Bohemian Paradise Region (NE Bohemia) were mentioned (but not figured) by Ziegler (2003) from Dolánky near Turnov, Hrubý Rohozec, Turnov, Ondříkovice and Sychrov. All these occurrences are of Late Turonian age. The record from East Bohemia (Choceň town) is rather problematic as the locality label was probably exchanged. The records of $D$. rugatum from Saxony (Germany) are mostly from the lower Strehlen Formation, i.e. the limestones of Strehlen and Weinböhla (see Tröger \& Voigt in Niebuhr et al. 2007). These occurrences correspond to the mid-Upper Turonian Hyphantoceras Event and are thus equivalent to the Hudcov Limestone in Bohemia. A single specimen comes from the lower 

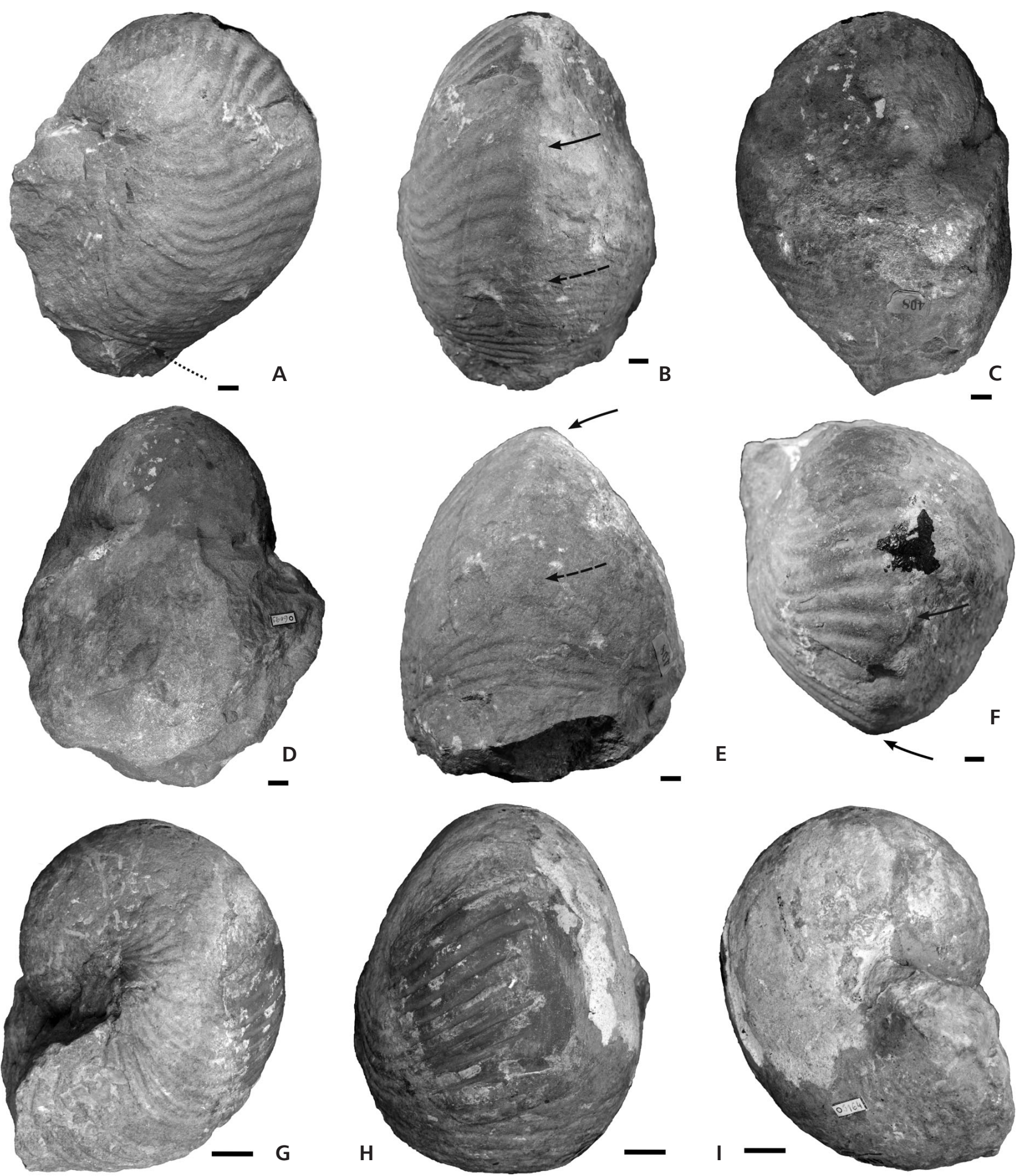

Figure 6. Deltocymatoceras rugatum (Fritsch \& Schlönbach, 1872). A-F - candidate neotype NM O 6093; A - left lateral side; B - ventral side; $\mathrm{C}$ - right lateral side; D - dorsal side; E - ventral side anterior view; F - ventral side posterior view. • G-I - syntype NM O 3164; G - left lateral side; $\mathrm{H}$ - ventral side; I - right lateral side. The dotted arrow shows the concentration of ribs in the apertural area. Full black arrows show the position of ventral keel. Dashed black arrows show the position of the disappearing ventral keel. The scale is equal $10 \mathrm{~mm}$.

Schrammstein Formation (Upper Turonian), which overlies the Zeichener Ton (Zeichen clay), an equivalent of the Hyphantoceras Event. The few records of D. leiotropis from northern Germany are from the Subhercynian Cretaceous Basin (nearshore sandstones of the Middle Coniacian Halberstadt Formation near Quedlinburg) and the Upper 


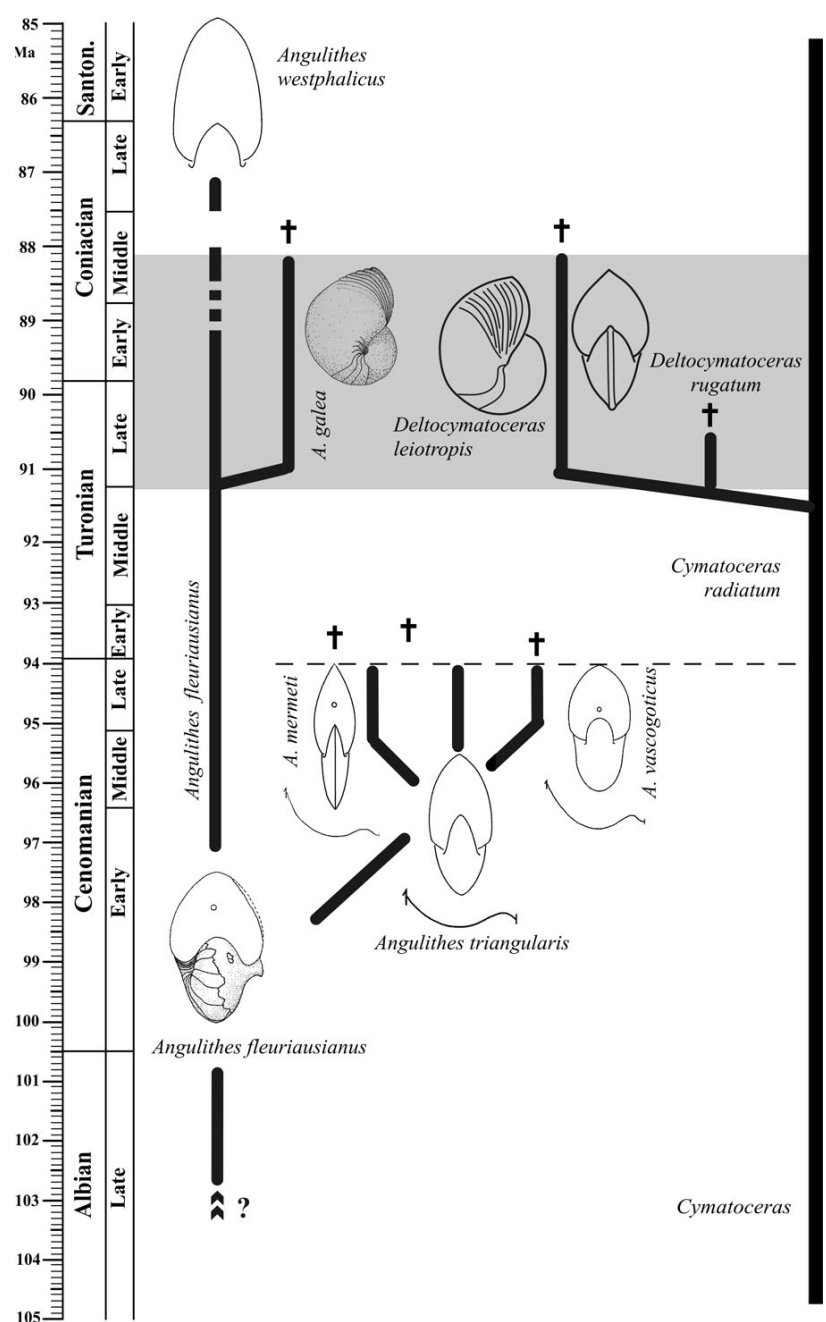

Figure 7. Inferred phylogeny of Deltocymatoceras, partly based on data from Dzik (1984) and Wilmsen (2000); absolute ages, after Ogg \& Hinnov (2012). The range of Deltocymatoceras is shaded in grey.

Turonian-Lower Coniacian proximal marly-glauconitic deposits of the southern Münsterland Cretaceous Basin (Salder and Erwitte formations; see Niebuhr et al. 2007). The holotype of D. leiotropis is not from the Emscher Formation (Middle Coniacian-Santonian) but most likely also of late Turonian age (see above). There are no records of the genus Deltocymatoceras from contemporaneous strata of the Danubian Cretaceous Group, south of the Bohemian Massif, developed in similar lithofacies as in Bohemia (Schneider et al. 2011). The single specimen of D. leiotropis from SW England is from the Chalk Rock, a condensed Upper Turonian lithostratigraphic unit. Another single specimen of $D$. cf. leiotropis from the $\mathrm{BCB}$ is reported from the Březno section (Ohře River) near Louny and is of late Early Coniacian age. It comes from the so-called "Gastropod Beds" sensu Frič (1894) of the Březno Formation. Stratigraphically, it belongs to the middle to upper part of the Cremnoceramus crassus inoceramid Zone in the uppermost part of the Foresteria petrocoriensis ammonite Zone. Ziegler (2003) recorded D. leiotropis from the Bohemian Paradise Region (Hrdoňovice) associated with Peroniceras tricarinatum (d'Orbigny), clearly documenting a Middle Coniacian age. Another fragmentary record, probably of D. leiotropis, is reported from the Borecké skály and Trosky hills, from the light yellowish-grey marls of the Březno Formation (Soukup 1963).

\section{Distribution pattern of Deltocymatoceras and its implications}

D. rugatum is exclusively known from the SaxoBohemian Cretaceous Basin, with the exception of a single record from the Opole trough in Poland (see Fig. 2). The basin was situated between the Mid-European (Rheno-Bohemian) Island in the south and west and the Lausitz and Sudetic blocks in the north (Fig. 2). During the Late Turonian, the Saxo-Bohemian Cretaceous Basin formed a narrow seaway linking the Boreal and the Tethyan Realms, the so-called "gateway to the Tethys". The basin was influenced several times by trophic changes, i.e. enrichment and depletion of nutrients (Wiese et al. 2004). The incursions of ribbed nautilids and/or local allopatric speciation are connected to changes in trophic conditions during the cooling phase of the "Hyphantoceras event", resulting in shallower water conditions in the Saxo-Bohemian Cretaceous Basin. D. rugatum occur in the Saxo-Bohemian Cretaceous Basin mainly in two facies reflecting deposition in different environments. While the nautilids inhabited hemipelagic environments (recorded by limestones) in NW Bohemia (Teplice Formation, Hudcov Limestone - Wiese et al. 2004) and Saxony (Strehlen and Weinböhla limestones), the other records are from the Jizera Formation indicating shallower water conditions with larger siliciclastic input (Uličný 2001). However, the bathymetric conditions in the two areas may not have been very different. At Úpohlavy (based on macrofossil biofacies), the basin depth probably did not exceed 60 meters, and in Central and NE Bohemia, the average water depth was around 30-40 $\mathrm{m}$ (the Trigonia/Choroušky beds).

The occurrence of D. rugatum in the Bohemian Cretaceous Basin is probably connected with another cephalopod faunal turnover caused by a marked cooling event in the terminal Middle Turonian or in the Middle/Upper Turonian boundary interval after the Middle Turonian thermal maximum (Voigt \& Wiese 2000, Wiese \& Voigt 2002, Wiese et al. 2004, Jarvis et al. 2006). The D. rugatum incursion, as in the "Hyphantoceras Event", was connected to the second cooling pulse (Phase III sensu Voigt \& Wiese 2000) in the middle part of the Subprionocyclus neptuni 

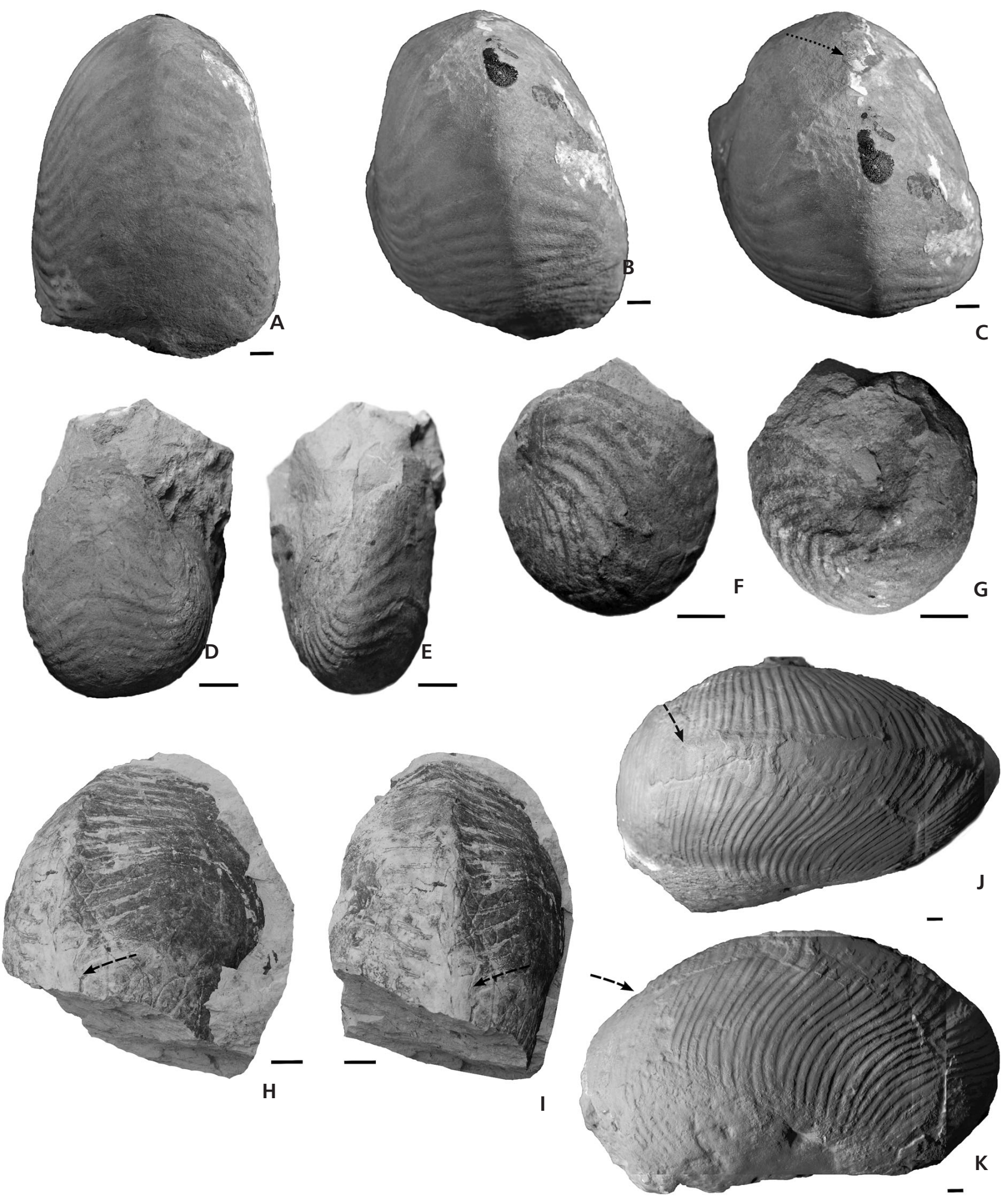

Figure 8. Ontogeny of Deltocymatoceras. $•$ A-I - Deltocymatoceras rugatum (Fritsch \& Schlönbach, 1872); A-C - specimen NM O 6417; C - appearance of the ventral keel. $\bullet$ D-G - juveniles with strong ribbing and without ventral keel; D, E - specimen MMG SaK 8469; F, G - specimen MMG SaK 8471. • H, I - specimen NM1-2010, onset of disappearance of the ventral keel. $\bullet$ J, K - Deltocymatoceras leiotropis (Schlüter, 1876), specimen MfN MB.C.15024, disappearance of ventral keel in late ontogeny. The dotted arrow shows the appearance of the ventral keel. Dashed black arrows show the position of the disappearing ventral keel. The scale is equal $10 \mathrm{~mm}$. 
ammonite Zone). This cooling event was associated with a marked sea-level lowstand. Probably, these conditions were highly suitable for nautilids including D. rugatum as well as other cephalopods (see below). Additionally, this cooling phase was accompanied by a southward shift of "exotic" faunas including Boreal ammonites and especially belemnites, typical inhabitants of the inner shelf areas (Košták \& Wiese 2011).

It is remarkable that not only D. rugatum shows a high degree of endemism. Other cephalopods known from D. rugatum-bearing horizons in the Saxo-Bohemian Cretaceous Basin, such as the belemnites $P$. bohemicus (Stolley) and P. aff. strehlensis (Fritsch \& Schlönbach; see Košták \& Wiese 2011) and the heteromorphic ammonites Allocrioceras strangulatum Wright and Eubostrychoceras saxonicum (Schlüter) also show a higher degree of endemism in European shelf seas. The majority of these cephalopod taxa are known from Germany, the Czech Republic, Poland, and partly from the Anglo-Paris Basin (Kaplan 1988, 1989; Košták et al. 2004).

D. rugatum became extinct shortly after its appearance (at the top of the Hudcov limestone in the BCB) in the Late Turonian. Strong predation pressure cannot be excluded as a potential reason as Ekrt et al. (2001) and Wiese et al. (2004) reported the highest vertebrate diversity in the lithounit $\mathrm{Xb}_{\alpha}$ (at the base). Marine reptiles and larger fishes (Ekrt et al. 2008), especially chondrichthyans (sharks and rays, 19 species), occurred (Wiese et al. 2004), including malacophagous taxa, which document a relatively high predation pressure. It is notable that this high predator diversity occurred approximately at the same level (base $\left.\mathrm{Xb}_{\alpha}\right)$ as the FA of D. rugatum.

Deltocymatoceras leiotropis is also very restricted in its palaeobiogeographic distribution, being known from northern Germany (Münsterland, Subhercynian area), the Saxo-Bohemian Cretaceous Basin and a single specimen from SW England (Fig. 2). According to the endemic occurrence of both species of Deltocymatoceras, there was no significant post-mortem dispersal (Reyment 2008). The single specimen from Chalk Rock (UK) most probably represents a stray individual and documents the low dispersion potential of Deltocymatoceras.

Deltocymatoceras is one of only a few endemic post-Triassic nautilids while early Palaeozoic cephalopods contain many endemic taxa derived from immigrants. Nevertheless, the vast majority of these endemic taxa are demersal nautilids (e.g. Barskov et al. 2008, Manda \& Turek 2009b, Turek \& Manda 2011) and endemism in coiled nautilids is quite rare. The distribution pattern of Cretaceous Deltocymatoceras to some degree corresponds to recent nautilids and reflects a decrease in steeled nautilids in late Mesozoic ecosystems.

\section{Competition - nautilids versus ammonites, and/or ecological substitution?}

Ecological interactions between nautilids and ammonoids have recently been discussed including their early co-occurrence in the Early Devonian (Barskov et al. 2008, Klug et al. 2010, Manda \& Turek 2011). Possible interaction between the two groups may aid understanding of the evolutionary pattern of ectocochleate cephalopods. To understand the unusual morphological features in nautilids described herein (depressed shell, prominent keel, strong ribs), a comparison with the only other ectocochleate, morphologically similar and a contemporaneous cephalopod group, i.e. ammonites, may be rewarding. In the case of D. rugatum, comprehensive and stratigraphically well calibrated data on the ammonite assemblage from the Úpohlavy working quarry may be used ( $c f$. Wiese et al. 2004). Based on a brief morphological analysis, we propose the idea that D. rugatum developed the described features as a reaction to the existence of a free ecological niche, i.e. the almost complete absence of medium-sized keeled ammonites (see below).

The ammonite assemblage recorded in the horizon with D. rugatum can be subdivided into five basic morphogroups inhabiting different environments:

1) Normally coiled (planispiral) ammonites represented by very large non-keeled Lewesiceras peramplum (Mantell) (> $50 \mathrm{~cm}$ in diameter) and smaller L. mantelli (Wright \& Wright) (microconchs about 8-10 cm; macroconchs up to $25-30 \mathrm{~cm}$ in diameter) and a single specimen (diameter $12 \mathrm{~cm}$ ) of the keeled ammonite $S u b$ prionocyclus cf. branneri (Anderson).

2) Heteromorphic (orthocone) ammonites (Baculites sp.) of different sizes varying between 6-20 cm.

3) Heteromorphic (scaphitocone) ammonites including Scaphites geinitzi (d'Orbigny) (numerous microconchs of 4-5 cm and macroconchs of 6-7 cm in diameter) and Yezoites bladenensis (Schlüter) (only a single specimen known).

4) Heteromorphic (open turriliticone to turriliticone) nostoceratid ammonites (Hyphantoceras reussianum (d'Orbigny), Eubostrychoceras saxonicum (Schlüter); incomplete specimens of about $10-15 \mathrm{~cm}$ in diameter).

5) Heteromorphic (toxocone) anisoceratid ammonites (Allocrioceras strangulatum Wright), only two incomplete specimens are recorded.

Identical ammonite faunas from the D. rugatum horizon are fragmentarily known from other parts of the SBCB (see above - Stratigraphic distribution section), for example E and NE Bohemia, where a predominance of Lewesiceras, Scaphites and some Baculites can be observed.

The majority of these taxa are heteromorphic ammonites with inferred planktonic (scaphitids - with different habitats in juvenile and adult stages - see Landman 
1987), benthic to nekto-benthic (nostoceratids) and pelagic (baculitids) life-style (e.g., Westermann 1996, Tsujita \& Westermann 1998). Only three species with planispiral shell - giant Lewesiceras peramplum, medium-sized L. mantelli and smaller $S$. cf. branneri were nektonic taxa. Within this group, the niche of medium sized $(20-30 \mathrm{~cm})$ ammonites is occupied only by non-keeled L. mantelli. Keeled S. cf. branneri (characterized by marked ornamentation - strong ribs and tubercles arranged in rows) is known only from a single incomplete specimen (found during the last 15 years of intensive collecting in the quarry this is probaly also the only specimen known from the Bohemian part of the SBCB). These observations suggest the almost complete absence of keeled ammonites in the critical interval inhabited by $D$. rugatum. Thus, we discuss the possibility of an expansion of Deltocymatoceras into an ecological niche which was actually not occupied by ammonites. Consequently, the similar morphological features developed in this nautilid genus (i.e. ribs, keel, size) should clearly document convergence with medium-sized, ribbed and keeled ammonites. This development seems to be highly specific for the SBCB and adjacent shelf seas, and it should also explain the high degree of endemism in the genus. However, the data are limited to date and our hypothesis needs to be tested in the future by further quantitative studies.

\section{Conclusions}

Deltocymatoceras is a rare Late Cretaceous nautilid genus comprising only two species characterized by bulbous shells with strong radial ribs and a ventral keel which appears in post-juvenile ontogenetic stages. This combination of morphological features is unique in post-Palaeozoic nautilids. The holotype of Deltocymatoceras leiotropis is for the first time photographically illustrated, accompanied by a detailed re-description. The majority of all known specimens of the species have been included in our revision. The revision revealed a narrow stratigraphic and endemic paleogeographic occurrence of $D$. leiotropis, which ranges from the Late Turonian to the Middle Coniacian with records from Germany, England, Poland and the Czech Republic. It is noteworthy that the type specimen stems from Upper Turonian strata in southern Münsterland (northern Germany) and not from the Middle Coniacian-Santonian. The only preserved syntype of D. rugatum is described and, according to its poor preservation and incomplete morphological features, a new candidate neotype is recommended. The species has a very short stratigraphic range (lower Upper Turonian) and occurs only in the Saxo-Bohemian Cretaceous Basin and in Poland. The phylogeny of Deltocymatoceras is discussed with two possible ancestors, i.e. Angulithes or Cymatoceras. Based on the similarity of juveniles of
Deltocymatoceras and Cymatoceras (inflated, strongly ribbed shells), a derivation from Cymatoceras radiatum is proposed. Despite the morphological affinities and presumable close phylogenetic relationship, we keep Deltocymatoceras as a separate genus based on its unique combination of strong ribbing and the development of a conspicuous keel. Some morphological changes in Deltocymatoceras during late ontogeny such as the disappearance of the ventral keel, the approximation of the last septa, rib crowding in the apertural area, the rounded broadening of the fully matured body chamber and an apertural constriction are comparable to other nautilids, both fossil (e.g., Angulithes) and Recent, and are interpreted as an expression of attaining and acquisition of maturity. These morphological changes during ontogeny (e.g. appearance of the ventral keel) are explained as potential adaptations to a change in lifestyle and habitat. The genus is a rare endemic taxon, which inhabited shallow water environments at the northern margin of the Mid European Island and in the vicinity of the Lausitz and the Sudetic blocks. All records come from shallow water siliciclastic environments and/or hemipelagic argillaceous carbonates and marls. A trigger for the appearance of Deltocymatoceras may be the sealevel fall associated with the "Hyphantoceras event" and the opening of an ecologic niche (i.e., lack of mediumsized, keeled ammonites at that time). The combination of the unusual morphological features developed in Deltocymatoceras may thus be a result of convergence with ammonites. However, the very short stratigraphic range of the genus (Late Turonian-Middle Coniacian, ca 3.5 Ma) reflects the limited evolutionary success of the "Deltocymatoceras model" combining hydrodynamically inefficient, bulbous, ribbed shells with a ventral keel. The rapid evolution and higher abundance of vertebrate predators in the Late Turonian may also have contributed to the rapid extinction of the genus. The stratigraphic range of Deltocymatoceras is very short for Late Cretaceous nautilids, especially for $D$. rugatum, the occurrence of which has the character of a bioevent. Its occurrence seems to be in direct relation to the "reussianum fauna" of the "Hyphantoceras event" in the middle part of the Late Turonian S. neptuni Zone of Central Europe. Thus, D. rugatum has a relatively high biostratigraphic potential for intrabasinal correlation.

\section{Acknowledgements}

We are very grateful to J. Sklenář (NM, Prague), U. Scheer (RM, Essen), S. Kaiser (GM, Bonn), D. Korn (MN, Berlin), L. Steel (NHM, London), H. Summesberger (NMW, Wien), P. Shepherd (BGS, Keyworth) and to the curators of the Czech regional museums for providing access to nautilid material; P. Kraft (Institute of Geology and Paleontology, Charles University, Prague), V. Turek, J. Vágner and especially J. Sklenář (Paleontological 
Department, Natural History Museum, National Museum Prague) are acknowledged for critical comments. Special thank go to S. Čech (Czech Geological Survey, Prague) for collecting two specimens of $D$. rugatum from Úpohlavy. We would like to thank the reviewers D. Stephen (University of Utah), R. Wani (Yokohama National University), C. Klug (University of Zurich), J. Dzik (Institute of Paleobiology, Polish Academy of Science) and the editor $\breve{S}$. Manda (Czech Geological Survey, Prague) for their very helpful comments. The research was supported by GAUK No. 13810, MSM 0021620855 and the authors thank the Ministry of Culture, the Czech Republic for financial support of the long term research concept in progress at this institute.

\section{References}

Agassiz, J.L.R. 1842-1847. Nomenclator zoologicus: continens nomina systematica generum animalium tam viventium quam fossilium, secundum ordinem alphabeticum disposita, adjectis auctoribus, libris, in quibus reperiuntur, anno editionis, etymologia et familiis, ad quas pertinent, in singulis classibus. 393 pp. Jent et Gassmann, Soloduri.

ANDERT, H. 1934. Die Kreideablagerungen zwischen Elbe und Jeschken. III. Die Fauna der obersten Kreide in Sachsen, Böhmen und Schlesien. Abhandlungen der Preußischen Geologischen Landesanstalt, Neue Folge 159, 1-477.

Barrande, J. 1865-1877. Systême silurien du Centre de la Bohême, I. ère partie: Recherches Paléontologiques, vol. II, Classe de Mollusques, Ordre des Céphalopodes, 1865. ser. 6, pl. 1-107; 1866. ser. 7, pl. 108-244; 1867. ser. 1, 712 pp.; 1868. ser. 8, pl. 245-350; 1870. ser. 2, 266 pp., ser. 9, pl. 351-460; 1874. ser. 3, 804 pp.; 1877. ser. 4, 742 pp., ser. 5, 743 pp., supplement 1, 297 pp., supplement 2, pl. 461-544. Privately published, Prague \& Paris.

Barskov, I.S., Boiko, M.S., Konovalova, V.A., Leonova, T.B. \& Nikolaeva, S.V. 2008. Cephalopods in the marine ecosystems of the Paleozoic. Paleontological Journal 42, 1167-1284. DOI 10.1134/S0031030108110014

Blainville, H.M.D. de 1825. Manuel de malacologie et de conchyliologie. 664 pp. Levrault, Paris.

Blanford, H.F. 1861. The fossil Cephalopoda of the Cretaceous rocks of southern India. I. Belemnitida-Nautilidae. Memoir of the Geological Survey of India, Palaeontologica Indica 1, 1-40.

Chamberlain, J.A. JR. 1976. Flow patterns and drag coefficients of cephalopod shells. Paleontology 19, 539-563.

Chamberlain, J.A. JR. \& Westermann, G.E.G. 1976. Hydrodynamic properties of cephalopod shell ornament. Paleobiology 2, 316-331.

Chirat, R. \& Bucher, H. 2006. Shell microstructure and morphogenesis of the ornamentation in Cymatoceras Hyatt, 1883, Cretaceous Nautilida. Systematic implications. Lethaia 39, 57-64. DOI 10.1080/00241160600582069

CichOwOLSKI, M. 2003. The nautiloid genus Cymatoceras from the Cretaceous of the Neuquén and Austral basins, Argentina. Cretaceous Research 24, 375-390. DOI 10.1016/S0195-6671(03)00050-8

Collins, D. \& WARD, P.D. 1987. Adolescent growth and maturity in Nautilus, 421-431. In Saunders, W.B. \& Landman, N.H. (eds) Nautilus: the biology and paleobiology of a living fossil. Plenum Press, New York \& London.

ConRad, T.A. 1866. Observation on Recent and fossil shells, with proposed new genera and species. American Journal of Conchology 2, 280-299.

Cullison, J.S. 1944. The stratigraphy of some Lower Ordovician formations of the Ozark uplift. University of Missouri School of Mines and Metallurgy Technical Series Bulletin 15, 1-112.

DzIK, J. 1984. Phylogeny of the Nautiloidea. Palaeontologia Polonica 45, 1-220.

Ekrt, B., KošŤÁk, M., Mazuch, M., ValíčeK, J., Voigt, S. \& WIESE, F. 2001. Short note on new records of late Turonian (Upper Cretaceous) marine reptiles remains from the Úpohlavy quarry (NM Bohemia, Czech Republic). Bulletin of Czech Geological Survey 76, 101-106.

Ekrt, B., KošŤÁx, M., Mazuch, M., Voigt, S. \& Wiese, F. 2008. New records of Teleosts from the Late Turonian (Late Cretaceous) of the Bohemian Cretaceous Basin (Czech Republic). Cretaceous Research 29, 659-674. DOI 10.1016/j.cretres.2008.01.013

FRANK, J. 2007a. Upper Cretaceous nautiloids of epicontinental seas in Central Europe - Bohemian Cretaceous Basin, 112-113. Seventh International Symposium Cephalopods Present and Past, Sapporo (Japan), Abstracts. Hokaido University, Sapporo.

FRANK, J. 2007b. Nautiloidea české křídové pánve, 35-36. 8. paleontologická konferencia, zborník abstraktov. S̆tátny geologický ústav Dionýza Štúra, Bratislava.

Frank, J. 2009. Deltocymatoceras galea (Fritsh, 1872), the remarkable Upper Cretaceous nautilid (Cephalopoda). $10^{\text {th }} \mathrm{An}$ niversary Conference of the Czech, Polish and Slovak Paleontologists, Abstracts, 13-14.

Frank, J. 2010. Taxonomy and palaeoecology of Cretaceous nautilids Angulithes galea (Fritsch in Fritsch \& Schlönbach, 1872) and Angulithes westphalicus (Schlüter, 1872). Bulletin of Geosciences 85, 487-496.

DOI 10.3140/bull.geosci.1194

FRIČ, A. 1883. Studien im Gebiete der Böhmischen Kreideformation; Palaeontologische Untersuchungen der einzelnen Schichten; III. Die Iserschichten. Archiv der naturwissenschaftlichen Landesdurchforschung von Böhmen 5, Geologische Abteilung, 1-144.

FRIČ, A. 1885. Studie v oboru křídového útvaru v Čechách. III. Jizerské vrstvy. Archiv pro přirodovědné prozkoumání Čech $5,1-132$.

FRIČ, A. 1889. Studien im Gebiete der böhmischen Kreideformation. IV. Die Teplitzer Schichten. Archiv Naturwissenschaften Landesdurchforschung Böhmen 7, Geologische Abteilung, 1-119.

FRIČ, A. 1893. Studien im Gebiete der Böhmischen Kreideformation. V. Priesener Schichten. Archiv Naturwissenschaften Landesdurchforschung Böhmen 9, Geologische Abteilung, $1-130$.

FrIČ, A. 1897. Studien im Gebiete der Böhmischen Kreideformation; Paläontologische Untersuchungen der einzelnen Schichten. VI. Die Chlomecker Schichten. Archiv der naturwissenschaftich Landesdurchforschung von Böhmen 10, Geologische Abteilung, 1-84.

Fritsch, A. \& SchlÖNBACh, U. 1872. Cephalopoden der böh- 
mischen Kreideformation. 52 pp. Published by the author, Prag.

GeinitZ, H.B. 1872-1875. Das Elbthalgebirge in Sachsen. Teil II: Der mittlere und obere Quader. Palaeontographica 20, $1-245$.

Gregory, F.J. 2001. Mesozoic Marine Revolution, 1-4. Encyclopedia of Life Sciences. Nature Publishing Group, London.

Hyatt, A. 1883-1884. Genera of fossil cephalopods. Proceedings of the Boston Society of Natural History 22, 253-338.

Jarvis, I., Gale, A.S., Jenkys, H.C. \& Pearce, M.A. 2006. Secular variation in Late Cretaceous carbon isotopes: a new $\delta^{13} \mathrm{C}$ carbonate reference curve for the Cenomanian-Turonian (99.6-70.6 Ma). Geological Magazine 143, 561-608. DOI 10.1017/S0016756806002421

Kaвамва, M. 1983. Les nautiles du Crétacé supérieur de Madagascar; contribution à l'étude de l'évolution des Nautiloïdes $d u$ Crétacé; systématique, phylogenie, biostratigraphie, paléoécologie, évolution. $148 \mathrm{pp}$. $\mathrm{PhD}$ thesis, University of Dijon, Dijon.

KaPlAN, U. 1988. Die heteromorphen Ammoniten de Gattungen Eubostrychoceras und Hyphantoceras au dem Turon NW-Deutschland. Geologie und Paläontologie in Westfalen 12, 47-87.

Kaplan, U. 1989. Die heteromorphe Ammonitengattung Allocrioceras Spath aus dem Turon von Nordwestdeutschland. Geologie und Paläontologie in Westfalen 15, 71-105.

KenNedy, W.J. 2002. Nautiloids, 219-231. In Smith, A.B. \& BATTEN, D.J. (eds) Fossils of the Chalk. Palaeontological Association Field Guide to Fossils 2 ( $2^{\text {nd }}$ ed.). The Paleontological Association, London.

Klug, C., Kröger, B., Kiessling, W., Mullins, G.L., Servais, T., FrÝdA, J., Korn, D. \& Turner, S. 2010. The Devonian nekton revolution. Lethaia 43(4), 465-477. DOI 10.1111/j.1502-3931.2009.00206.x

KNER, R. 1848. Versteinerungen des Kreidemergels von Lemberg und seiner Umgebung. W. Haidinger's Naturwissenschaftliche Abhandlungen 3, 1-42.

KošŤÁk, M., Čech, S., Ekrt, B., Mazuch, M., Wiese, F., Voigt, S. \& Wood, C.J. 2004. Belemnites of the Bohemian Cretaceous Basin in a global context. Acta Geologica Polonica 54, 511-533.

KoŠŤÁK, M. \& WIESE, F. 2011. Extremely rare Turonian belemnites from the Bohemian Cretaceous Basin and their palaeogeographical importance. Acta Palaeontologica Polonica 56, 433-437. DOI 10.4202/app.2009.0065

Kummel, B. 1956. Post-Triassic Nautiloid genera. Bulletin of the Museum of Comparative Zoology at Harvard College in Cambridge 114, 319-494.

Kummel, B. 1964. Nautiloidea-Nautilida, K383-K457. In Moore, R.C. (ed.) Treatise on Invertebrate Paleontology, Part K, Mollusca 3. Geological Society of America \& University of Kansas Press, Boulder \& Lawrence.

Landman, N.H. 1987. Ontogeny of Upper Cretaceous (Turonian-Santonian) scaphitid ammonites from the Western Interior of North America: systematics, developmental patterns, and life history. Bulletin of the American Museum of Natural History $185,117-241$.

MANDA, Š. 2008. Palaeoecology and palaeogeographic relations of the Silurian phragmoceratids (Nautiloidea, Cephalopoda) of the Prague Basin (Bohemia). Bulletin of Geosciences 83(1), 39-62. DOI 10.3140/bull.geosci.2008.01.039

MANDA, Š. \& FRÝDA, J. 2010. Silurian-Devonian boundary events and their influence on cephalopod evolution: evolutionary significance of cephalopod egg size during mass extinctions. Bulletin of Geosciences 85(3), 513-540.

DOI 10.3140/bull.geosci.1174

Manda, Š. \& Turek, V. 2009a. Revision of the Pragian Rutoceratoidea Hyatt, 1884 (Nautiloidea, Oncocerida) from the Prague Basin. Bulletin of Geosciences 84(1), 127-148.

DOI 10.3140/bull.geosci.1118

MANDA, Š. \& TuREK, V. 2009b. Minute Silurian oncocerid nautiloids with unusual colour patterns. Acta Palaeontologica Polonica 54(3), 503-512. DOI 10.4202/app.2008.0062

Manda, Š. \& TuReK, V. 2011. Colour pattern polymorphism in Silurian nautiloid Phragmoceras Broderip, 1839. Bulletin of Geosciences 86(1), 91-105. DOI 10.3140/bull.geosci.1240

Matsumoto, T. \& Muramoto, K. 1983. Cretaceous Nautiloids from Hokkaido. Three Nautiloid species from the Santonian and Campanian of Hokkaido. Transactions and Proceedings of the Palaeontological Society of Japan, New Series 130, $85-95$.

Mojsisovics, E. 1873-1902. Die Cephalopoden der Hallstätter Kalke. Abhandlungen der geologischen Reichsanstalt 6, $1-354$.

MontFort, D. 1808. Conchyliologie systèmatique et classification méthodique des coquilles; offrant leurs figures, leur arrangement générique, leurs descriptions caractéristiques, leur noms; ainsi que leur synonymie en plusieurs langues. Conchyliologie systèmatique. Tome premiere. 409 pp. F. Schoell, Paris.

OGG, J.G. \& Hinnov, L.A. 2012. Cretaceous, 793-853. In GradStein, F.M., OgG, J.G., Schmitz, M. \& OGG, G.M. (eds) The geologic time scale 2012, Volume 2. Elsevier, Amsterdam.

Orbigny, A. D' 1840-1842. Paléontologie Française. Terrain Crétacé I, Céphalopodes. 662 pp. Masson, Paris.

Niebuhr, B., Hiss, M., Kaplan, U., Tröger, K.-A., Voigt, S., Voigt, T., Wiese, F. \& WiLmsen, M. 2007. Lithostratigraphie der norddeutschen Oberkreide. Schriftenreihe der Deutschen Gesellschaft für Geowissenschaften 55, 1-136.

Philip, J. \& Floquet, M. 2000. Late Cenomanian (94.7-93.5), 129-136. In Dercourt, J., Gaetani, M., Vrielynck, B., BarRier, E., Biju-Duval, B., Brunet, M.F., Cadet, J.P., CrasQuin, S. \& Sandulescu, M. (eds) Atlas Peri-Tethys palaeogeographical maps. CCGM/CGMW, Paris.

PIEPER, B. 1990. Erläuterungen zu Blatt 4508 Essen. Geologische Karte von Nordrhein-Westfalen 1:25000 ( $2^{\text {nd }}$ ed.), Blatt 4508. 136 pp. Geologisches Landesamt Nordrhein-Westfalen, Essen.

Reuss, E.A. 1845-46. Die Versteinerungen der böhmischen Kreideformation. Part 1 (1845), 58 pp.; Part 2 (1846), 148 pp. E. Schweitzerbart'sche Verlagsbuchhandlung, Stuttgart.

Reyment, R.A. 2008. A Review of the post-mortem dispersal of cephalopod shells. Palaeontologia Electronica 11, http://palaeo-electronica.org/2008_3/148/index.html, 1-13.

SCHLÜTER, C. 1871-1876. Cephalopoden der Oberen Deutschen Kreide. Palaeontographica. 263 pp. Theodor Fischer, Bonn.

Schneider, S., Niebuhr, B., Wilmsen, M. \& VodréžKa, R. 2011. 
Between the Alb and the Alps - The fauna of the Upper Cretaceous Sandbach Formation (Passau region, SE Germany). Bulletin of Geosciences 86(4), 785-816.

DOI 10.3140/bull.geosci.1279

ShimANSKy, V.N. 1975. Cretaceous nautiloids. Trudy Paleontologicheskogo instituta Akademii nauk SSSR 150, 1-208. [in Russian]

Signor, P.W. III \& Brett, C.E. 1984. The mid-Paleozoic precursor to the Mesozoic marine revolution. Paleobiology 10, 229-245.

SouKuP, J. 1963. Křída, 62-113. In ČЕРEK, L. (ed.) Vysvětlivky k prehledné geologické mapě, list M-33-XVI, Hradec Králové. NČSAV, Praha.

SowERBY, J. 1822. No. LVI of the mineral conchology of Great Britain; or colored figures and descriptions of those remains of testaceous animals or shells, which have been preserved at various times and depths in the Earth. The Mineral Conchology of Great Britain 4, 17-24.

Sowerby, J. DE C. 1824. No. LXXXII of the mineral conchology of Great Britain; or colored figures and descriptions of those remains of testaceous animals or shells, which have been preserved at various times and depths in the Earth. The Mineral Conchology of Great Britain 5, 115-130.

Spath, L.F. 1919. Notes on Ammonites III. Geological Magazine 56, 115-122. DOI 10.1017/S0016756800202276

SpATH, L.F. 1927. Revision of the Jurassic cephalopod fauna of Kachh (Cutch). Memoir of the Geological Survey of India, Paleontologica Indica, New Series 9(1), 1-71.

SPENGLER, E. 1910. Untersuchungen über die Südindische Kreideformation. 4. Die Nautiliden und Belemniten des Trichinopolydistrikts. Beiträge für Pälaontologie und Geologie Osterreich-Ungarns und des Orients 23, 125-157.

STRIDSBERG, S. 1985. Silurian oncocerid cephalopods from Gotland. Fossils and Strata 18, 1-65.

Teichert, C. 1964. Morphology of hard parts, K13-K53. In Moore, R.C. (ed.) Treatise on Invertebrate Paleontology, Part K, Mollusca 3. Geological Society of America \& University of Kansas Press, Boulder \& Lawrence.

TinTANT, H. 1989. Les avatars ontogénétiques et phylogénétiques de l'ornementation chez les nautiles post-triasiques, 357-367. In David, B., Dommergues, J.-L., Chaline, J. \& Laurin, B. (eds) Colloque international CNRS: Ontogenèse et Evolution, Dijon 1986. Géobios, Mémoire Spécial 12.

Tintant, H., Marchand, D. \& Mouterde, R. 1982. Relations entre les milieux marins et l'évolution des Ammonoïdés: les radiations adaptatives du Lias. Bulletin de la Société géologique de France 7, 951-761.

Tintant, H. \& KaBAmba, M. 1985. The role of the environment in the Nautilaceae, 58-66. In BAyer, U. \& SeILACher, A. (eds) Sedimentary and evolutionary cycles. Lecture Notes in Earth Sciences 1.

Tsujita, C.J. \& Westermann, G.E.G. 1998. Ammonoid habitats and habits in the Western Interior Seaway: a case study from the Upper Cretaceous Bearpaw Formation of southern Alberta, Canada. Palaeogeography, Palaeoclimatology, Palaeoecology 144, 135-160. DOI 10.1016/S0031-0182(98)00090-X

ULIČNÝ, D. 2001. Depositional systems and sequence stratigraphy of coarse-grained deltas in a shallow-marine, strike-slip set- ting: the Bohemian Cretaceous Basin, Czech Republic. Sedimentology 48, 599-628.

DOI 10.1046/j.1365-3091.2001.00381.x

Vermeis, G.J. 1977. The Mesozoic marine revolution: evidence from snails, predators and grazers. Paleobiology 3, $245-258$.

Voigt, S. \& Wiese, F. 2000. Evidence for late Cretaceous (Late Turonian) climate cooling from oxygen-isotope variations and palaeobiogeographic changes in Western and Central Europe. Journal of the Geological Society 157, 737-743.

DOI 10.1144/jgs.157.4.737

WARD, P. 1981. Shell sculpture as a defensive adaption in ammonoids. Paleobiology 7, 96-100.

Westermann, G.E.G. 1971. Form, structure and function of shell and siphuncle in coiled Mesozoic ammonoids. Royal Ontario Museum, Life Sciences, Contributions 78, 1-39.

Westermann, G.E.G. 1996. Ammonoid life and habitat, 607-707. In Landmann, N.H., Tanabe, K. \& Davies, R.A. (eds) Ammonoid Paleobiology. Plenum Press, New York \& London.

WiedmanN, J. 1960. Zur Systematik jungmesozoischer Nautiliden. Palaeontographica, Abteilung A 115, 144-206.

Wiese, F., ČECh, S., Ekrt, B., KošŤÁK, M., MAZUch, M. \& Voigt, S. 2004. The Upper Turonian of the Bohemian Cretaceous Basin (Czech Republic) exemplified by the Úpohlavy working quarry: integrated stratigraphy and palaeoceanography of a gateway to the Tethys. Cretaceous Research 25, 329-352. DOI 10.1016/j.cretres.2004.01.003

Wiese, F. \& Voigt, S. 2002. Late Turonian (Cretaceous) climate cooling in Europe: faunal response and possible causes. Geobios 35, 65-77. DOI 10.1016/S0016-6995(02)00010-4

Wilmsen, M. 2000. Late Cretaceous nautilids from northern Cantabria, Spain. Acta Geologica Polonica 50, 29-43.

Wilmsen, M. \& Esser, K. 2004. Latest Campanian to Early Maastrichtian (Cretaceous) nautiloids from the white chalk of Kronsmoor, northern Germany. Acta Geologica Polonica 54, 489-498.

Wilmsen, M. \& Mosavinia, A. 2011. Phenotypic plasticity and taxonomy of Schloenbachia varians (J. Sowerby, 1817). Paläontologische Zeitschrift 85, 169-184. DOI 10.1007/s12542-010-0086-5

Wilmsen, M. \& YazyKova, E.A. 2003. Campanian (Late Cretaceous) nautiloids from Sakhalin, Far East Russia. Acta Palaeontologica Polonica 48, 481-490.

Wittler, F.A., Roth, R. \& Legant, J. 1999. Die Nautiliden der oberen Kreide vom Süd- und Westrand des Münsterländer Beckens. Arbeitskreis Paläontologie Hannower 27, 1-52.

ZAHÁLKA, Č. 1900a. Pásmo IX (Březenské) křídového útvaru v Poohří. Věstník Královské České společnosti nauk, Třída mathematicko-přirodovědná 1899, 1-103.

ZaHÁlKa, Č. 1900b. Pásmo X (Teplické) křídového útvaru v Poohří. Věstník Královské České společnosti nauk, Třída mathematicko-přirodovědná 1899, 1-51.

ZIEGLER, P.A. 1990. Geological atlas of Western and Central Europe. $2^{\text {nd }}$ edition. 239 pp. Shell Internationale Petroleum Maatschappij B.V., The Hague.

ZIEGLER, V. 2003. Stratigrafie kř́dových sedimentů v oblasti Českého ráje. 96 pp. Pedagogická fakulta, Univerzita Karlova v Praze, Praha. 


\section{Appendix}

List of specimens

\begin{tabular}{|c|c|c|c|c|c|c|}
\hline Collections & Specimen & Old determination & $\begin{array}{l}\text { New } \\
\text { determination }\end{array}$ & Locality & Stratigraphy & Age \\
\hline \multicolumn{7}{|c|}{ Deltocymatoceras rugatum (Fritsch \& Schlönbach, 1872) } \\
\hline NM Prague - CZ & $\begin{array}{l}\text { O } 3164- \\
\text { syntype }\end{array}$ & Nautilus rugatus & D. rugatum & Choroušky; Czech Republic & Jizera Formation & Upper Turonian \\
\hline NM Prague $-\mathrm{CZ}$ & $\begin{array}{l}\text { O } 6093- \\
\text { candydate } \\
\text { neotype }\end{array}$ & Nautilus rugatus & D. rugatum & Choroušky; Czech Republic & Teplice Formation & Upper Turonian \\
\hline NM Prague - CZ & $\begin{array}{l}\text { new number } \\
\text { NM1-2010 }\end{array}$ & D. rugatus & D. rugatum & Úpohlavy; Czech Republic & $\begin{array}{l}\text { Teplice Formation, } \\
\text { Lower Coprolite Beds }\end{array}$ & Upper Turonian \\
\hline NM Prague - CZ & $\begin{array}{l}\text { new number } \\
\text { NM2-2010 }\end{array}$ & D. rugatus & D. rugatum & Úpohlavy; Czech Republic & $\begin{array}{l}\text { Teplice Formation, } \\
\text { Lower Coprolite Beds }\end{array}$ & Upper Turonian \\
\hline NM Prague - CZ & O 6417 & Nautilus rugatus & D. rugatum & Choroušky; Czech Republic & Jizera Formation & Upper Turonian \\
\hline NM Prague - CZ & $\mathrm{d} 44 / 2006$ & D. rugatus & D. rugatum & Úpohlavy; Czech Republic & $\begin{array}{l}\text { Teplice Formation, } \\
\text { Upper Coprolite Beds, } \\
\text { Kt3-XbIX }\end{array}$ & Upper Turonian \\
\hline \multicolumn{2}{|c|}{ ChM ÚGP Prague - CZ IGP 9446} & Nautilus rugatus & D. rugatum & $\begin{array}{l}\text { Hundorf/Teplice; Czech } \\
\text { Republic }\end{array}$ & Teplice Formation & Upper Turonian \\
\hline \multicolumn{2}{|c|}{ ChM ÚGP Prague - CZ IGP 7913} & Nautilus rugatus & D. rugatum & $\begin{array}{l}\text { Rovensko pod Troskami; } \\
\text { Czech Republic }\end{array}$ & Jizera Formation & Upper Turonian \\
\hline \multicolumn{2}{|c|}{ ChM ÚGP Prague - CZ IGP 2013/3 } & Nautilus rugatus & D. rugatum & $\begin{array}{l}\text { Hundorf/Teplice; Czech } \\
\text { Republic }\end{array}$ & Teplice Formation & Upper Turonian \\
\hline PMN Nymburk - CZ & D43 & Nautilus sp. & D. rugatum & $\begin{array}{l}\text { Hrubý Jeseník; Czech } \\
\text { Republic }\end{array}$ & $\begin{array}{l}\text { Jizera-Teplice } \\
\text { formations }\end{array}$ & Upper Turonian \\
\hline MCR Turnov - CZ & P 543 & Nautilus rugatus & D. rugatum & & & Upper Turonian \\
\hline OM Choceň - CZ & & Nautilus rugatus & D. rugatum & Choceň; Czech Republic & $\begin{array}{l}\text { Jizera-Teplice } \\
\text { formations }\end{array}$ & Upper Turonian \\
\hline M Železnice - CZ & MZ 3/13 & Nautilus & D. rugatum & Železnice; Czech Republic & Jizera Formation & Upper Turonian \\
\hline Úpohlavy quarry - CZ & no number yet & none & D. rugatus & Úpohlavy; Czech Republic & $\begin{array}{l}\text { Teplice Formation, } \\
\text { Upper Coprolite Beds }\end{array}$ & Upper Turonian \\
\hline RME Essen - DE & $\begin{array}{l}\text { RE 551.763.320 } \\
\text { (A 0708/1) }\end{array}$ & Nautilus rugatus & D. rugatum & Oppeln/Opole; Poland & Opole & Upper Turonian \\
\hline MMG Dresden - DE & SaK 8469 & Nautilus rugatus & D. rugatum & $\begin{array}{l}\text { Dresden - Weinböhla; } \\
\text { Germany }\end{array}$ & Strehlen Formation & Upper Turonian \\
\hline MMG Dresden - DE & SaK 8471 & Nautilus rugatus & D. rugatum & $\begin{array}{l}\text { Dresden - Weinböhla; } \\
\text { Germany }\end{array}$ & Strehlen Formation & Upper Turonian \\
\hline MMG Dresden - DE & SaK 8476 & Nautilus rugatus & D. rugatum & $\begin{array}{l}\text { Dresden - Weinböhla; } \\
\text { Germany }\end{array}$ & Strehlen Formation & Upper Turonian \\
\hline MMG Dresden - DE & SaK 10007 & Nautilus rugatus & D. rugatum & Dresden - Strehlen; Germany & Strehlen Formation & Upper Turonian \\
\hline MMG Dresden - DE & SaK 10009 & Nautilus rugatus & D. rugatum & Dresden - Strehlen; Germany & Strehlen Formation & Upper Turonian \\
\hline MMG Dresden - DE & SaK 10010 & Nautilus rugatus & D. rugatum & Dresden - Strehlen; Germany & Strehlen Formation & Upper Turonian \\
\hline MMG Dresden - DE & SaK 10015 & Nautilus elegans & D. rugatum & Dresden - Strehlen; Germany & Strehlen Formation & Upper Turonian \\
\hline MMG Dresden - DE & SaK 10016 & Nautilus elegans & D. rugatum & Dresden - Strehlen; Germany & Strehlen Formation & Upper Turonian \\
\hline \multicolumn{7}{|c|}{ Deltocymatoceras leiotropis (Schlüter, 1876) } \\
\hline GMB Bonn - DE & $\begin{array}{l}96(\mathrm{GM}-42)- \\
\text { holotype }\end{array}$ & Nautilus leiotropis & D. leiotropis & $\begin{array}{l}\text { Hercules mine in Essen; } \\
\text { Germany }\end{array}$ & $\begin{array}{l}\text { Oerlinghausen or } \\
\text { Salder Formation }\end{array}$ & $\begin{array}{l}\text { (?Middle to) } \\
\text { Upper Turonian }\end{array}$ \\
\hline MfN Berlin - DE & $\begin{array}{l}\text { MB.C. } 15024 \\
\text { (A } 24-\text { copy) }\end{array}$ & Nautilus leiotropis & D. leiotropis & $\begin{array}{l}\text { Lehofsberg near Quedlinburg; } \\
\text { Germany }\end{array}$ & Halberstadt Formation & $\begin{array}{l}\text { Middle } \\
\text { Coniacian }\end{array}$ \\
\hline BGS Keyworth - UK & GSM 117523 & Deltonautilus & D. leiotropis & $\begin{array}{l}\text { Hitch Wood Chalkquarry, } \\
\text { St. Paul Walden Heights; UK }\end{array}$ & $\begin{array}{l}\text { Upper Chalk, Chalk } \\
\text { Rock, } \\
\text { Subprionocyclus } \\
\text { neptuni Zone }\end{array}$ & Upper Turonian \\
\hline
\end{tabular}


Bulletin of Geosciences • Vol. 88, 4, 2013

\begin{tabular}{|c|c|c|c|c|c|c|}
\hline Collections & Specimen & Old determination & $\begin{array}{l}\text { New } \\
\text { determination }\end{array}$ & Locality & Stratigraphy & Age \\
\hline MMG Dresden - DE & SaK 6379 & Nautilus leiotropis & ?D. leiotropis & Wehlen; Germany & $\begin{array}{l}\text { Schrammstein } \\
\text { Formation }\end{array}$ & Upper Turonian \\
\hline NHM London - UK & C. 15226 & Nautilus leiotropis & ?D. leiotropis & $\begin{array}{l}\text { Halberstadt, Saxony-Anhalt; } \\
\text { Germany }\end{array}$ & $\begin{array}{l}\text { lower Emscher } \\
\text { Formation }\end{array}$ & $\begin{array}{l}\text { (Lower-Middle) } \\
\text { Coniacian }\end{array}$ \\
\hline MfN Berlin - DE & MB.C. 13922 & none & D. leiotropis & $\begin{array}{l}\text { Bystrzyca Kłodzka } \\
\text { (= Habelschwerdt), Poland }\end{array}$ & "Emscher" & Coniacian \\
\hline $\begin{array}{l}\text { Wittler et al. (1999) } \\
\text { p. } 35 \text {, text-fig. } 45 \mathrm{a}, \mathrm{b}\end{array}$ & & D. leiotropis & D. leiotropis & Dortmund - Mitte; Germany & Erwitte Formation & Lower Coniacian \\
\hline $\begin{array}{l}\text { Wittler et al. (1999) } \\
\text { p. 36, text-fig. 46a, b }\end{array}$ & & ?D. sp. & ?D.leiotropis & $\begin{array}{l}\text { Dortmund - Wambel; } \\
\text { Germany }\end{array}$ & Salder Formation & $\begin{array}{l}\text { lower Upper } \\
\text { Turonian }\end{array}$ \\
\hline NM Prague $-\mathrm{CZ}$ & $\begin{array}{l}\text { O 6604 } \\
\text { (d 169/2005) }\end{array}$ & $\begin{array}{l}\text { Nautilus rugatus - } \\
\text { N. leiotropis }\end{array}$ & D. leiotropis & Březno; Czech Republic & Brezno Formation & Lower Coniacian \\
\hline NMW Vienna - AT & NHMW 24 & Nautilus sp. & D. leiotropis & $\begin{array}{l}\text { Hundorf/Teplice; Czech } \\
\text { Republic }\end{array}$ & Teplice Formation & Upper Turonian \\
\hline \multicolumn{7}{|c|}{ In open nomenclature due to preservation } \\
\hline RMT Teplice - CZ & PA 1328 & Nautilus sp. & D. rugatum? & $\begin{array}{l}\text { Hundorf/Teplice; Czech } \\
\text { Republic }\end{array}$ & Teplice Formation & Upper Turonian \\
\hline NHM London - UK & C. 15578 & $\begin{array}{l}\text { Nautilus } \\
\text { leiotropis? }\end{array}$ & D. sp. & Wickham, Strood, Kent; UK & zone Holaster planus & Turonian \\
\hline MMG Dresden - DE & SaK 9994 & Nautilus rugatus & $D . \mathrm{sp}$. & Dresden - Strehlen; Germany & Strehlen Formation & Upper Turonian \\
\hline MMG Dresden - DE & SaK 9995 & Nautilus rugatus & $D . \mathrm{sp}$. & Dresden - Strehlen; Germany & Strehlen Formation & Upper Turonian \\
\hline MMG Dresden - DE & SaK 9996 & $\begin{array}{l}\text { Nautilus } \\
\text { sublaevigatus }\end{array}$ & D. sp. & Dresden - Strehlen; Germany & Strehlen Formation & Upper Turonian \\
\hline MMG Dresden - DE & SaK 9997 & Nautilus rugatus & D. sp. & Dresden - Strehlen; Germany & Strehlen Formation & Upper Turonian \\
\hline MMG Dresden - DE & SaK 10006 & Nautilus rugatus & D. sp. & Dresden - Strehlen; Germany & Strehlen Formation & Upper Turonian \\
\hline $\begin{array}{l}\text { Wittler et al. (1999) } \\
\text { p. 22, text-fig. 26a, b }\end{array}$ & & $\begin{array}{l}\text { ?Cymatoceras } \\
\text { sharpei }\end{array}$ & $\begin{array}{l}\text { D. sp. or } \\
\text { A. galea }\end{array}$ & $\begin{array}{l}\text { Dortmund - Wambel; } \\
\text { Germany }\end{array}$ & Salder Formation & Upper Turonian \\
\hline
\end{tabular}

